\title{
The Paleoproterozoic Hedesunda granite complex, east-central Sweden, a composite intrusion
}

\author{
Åke Johansson ${ }^{1}$ (1) \\ Received: 11 February 2020 / Accepted: 17 May 2020 / Published online: 2 July 2020 \\ (c) The Author(s) 2020
}

\begin{abstract}
The Hedesunda granite complex covers a rectangular area of ca $800 \mathrm{~km}^{2}$ within the Bergslagen lithotectonic unit of the Paleoproterozoic Svecofennian orogen in east-central Sweden. It is dominated by coarse porphyritic and generally undeformed granitoids whose position within the Svecofennian orogenic evolution has been controversial. New U-Pb SIMS dating of zircon confirms earlier TIMS results, showing that it is a composite intrusion made up of an older phase at ca $1865 \mathrm{Ma}$, forming the bulk of the massif, and a younger phase at ca $1785 \mathrm{Ma}$, forming a circular intrusion in the north-central area and an elongated body further west. The two generations have very different geochemistry. The older Hedesunda I intrusion ranges from diorite through tonalite and granodiorite to granite in composition, is dominantly metaluminous, calc-alkaline, magnesian, I-type and volcanic arc-related, and probably formed by melting of juvenile Svecofennian lower crust due to basaltic underplating during an extensional 'intra-orogenic' phase shortly after the main subduction-related early-orogenic Svecofennian magmatism. The younger Hedesunda II intrusions are purely granitic, dominantly peraluminous, alkali-calcic, K-rich, and ferroan, with A-type and within-plate-type characteristics, and formed penecontemporaneously with post-collisional shoshonitic intrusions in southern Finland, again presumably by crustal melting due to basaltic underplating in an extensional setting towards the end of the Svecofennian orogeny.
\end{abstract}

Keywords Hedesunda granite massif · Bergslagen · Svecofennian $\cdot$ Sweden $\cdot$ U-Pb dating $\cdot$ Granite geochemistry

\section{Introduction and geological background}

The Paleoproterozoic Hedesunda granite complex in eastcentral Sweden is straddling the boundary between Uppsala and Gävleborg counties along the lower part of the Dalälven river ca $120 \mathrm{~km}$ north of Stockholm (Fig. 1). In geological terms, it is located in the Bergslagen lithotectonic unit of the Svecofennian (also known as Svecokarelian) orogenic province (cf. Stephens et al. 2009; Stephens and Andersson 2015; Stephens and Jansson 2020). The Bergslagen region is well known for its iron and sulphide ore deposits, formed in close connection with felsic volcanism around $1900 \mathrm{Ma}$

Electronic supplementary material The online version of this article (https://doi.org/10.1007/s00531-020-01885-x) contains supplementary material, which is available to authorized users.

Åke Johansson

ake.johansson@nrm.se

1 Department of Geosciences, Swedish Museum of Natural History, Box 50 007, 10405 Stockholm, Sweden ago, and mined continuously from the Middle Ages (and possibly earlier) to present time.

Modern and exhaustive descriptions of the geology of the Bergslagen region are found in Stephens et al. (2009) and Stephens and Jansson (2020), including summaries of geochemical and geochronological data. Most of the currently exposed crust formed in connection with subductionrelated magmatism at $1.91-1.87 \mathrm{Ga}$, including ore-bearing felsic to intermediate metavolcanic rocks and associated metasediments, as well as early-orogenic intrusive rocks [the 1.91-1.87 Ga Granitoid-Dioritoid-Gabbroid (GDG) suite of Stephens et al. (2009)]. This was followed closely by pervasive deformation and low-pressure metamorphism, dominantly in amphibolite facies, with associated migmatization at 1.87-1.85 Ga (Stephens et al. 2009; Stephens and Andersson 2015; Johansson and Stephens 2017; Stephens and Jansson 2020). After an apparently quieter 'intra-orogenic' period, there was a second period of metamorphism at $1.82-1.75 \mathrm{Ga}$, more prevalent further south than in the Hedesunda area (Stephens and Andersson 2015), and intrusion of late-orogenic granites [Granite-Pegmatite (GP) suite 


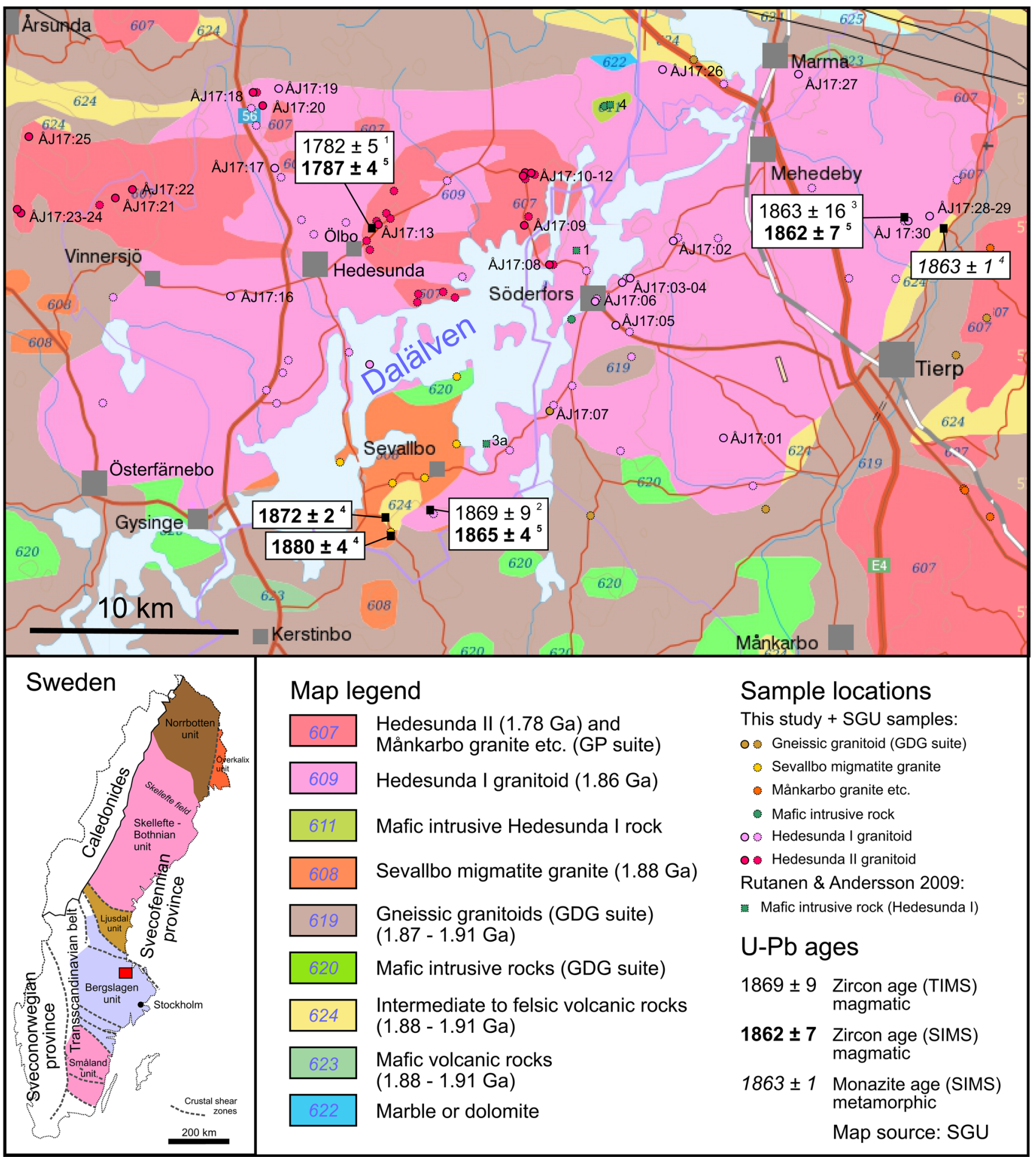

Fig. 1 Geological bedrock map of the Hedesunda area from the digital map service of the Geological Survey of Sweden (SGU; https:// apps.sgu.se/kartvisare/kartvisare-berggrund-1-miljon.html), with location of analysed samples [labelled symbols = this study; unlabelled symbols $=$ samples from the SGU database; mafic rock samples 1, 3a, and 3 from Rutanen and Andersson (2009)]. Also shown are obtained $\mathrm{U}-\mathrm{Pb}$ ages from the area (references: $1=$ Persson and
Persson 1997; $2=$ Bergman et al. 2004; $3=$ Stephens et al. 2009; $4=$ Johansson and Stephens 2017; 5=This study). GDG Granitediorite-gabbro suite of Stephens et al. (2009), GP Granite-pegmatite suite of Stephens et al. (2009). Inset map of Sweden shows the location of the Hedesunda area and the recent subdivision of the Svecofennian province (aka Svecokarelian province) in Sweden into different lithotectonic units by the Geological Survey of Sweden 
of Stephens et al. (2009)], at least in part considered to be of crustal anatectic origin.

In addition to the early-orogenic GDG magmatism and the late-orogenic GP magmatism, Stephens et al. (2009) also introduced the term Granitoid-Syenitoid-Dioritoid-Gabbroid (GSDG) magmatism for rocks following a more alkali-rich trend. Such rocks formed during three periods, at $1.87-1.84 \mathrm{Ga}, 1.81-1.78 \mathrm{Ga}$, and $1.70-1.67 \mathrm{Ga}$, with the last two periods confined to rocks belonging to the Transscandinavian Igneous Belt (TIB) west of the Bergslagen region proper (TIB-1 and TIB-2 rocks, respectively), and the first period encompassing rocks in the border zone to the Transscandinavian Belt (TIB-0 rocks), but also including the older phase of the Hedesunda granite complex.

While the early-orogenic phase is generally considered to be accretionary and subduction-related, the late-orogenic phase has traditionally been regarded as collision-related. In more recent plate tectonic interpretations, it is often associated with oblique collision between Fennoscandia and Sarmatia from the present southeast (e.g. Bogdanova et al. 2015). However, Hermansson et al. (2008) presented a purely accretionary scenario involving tectonic switching between compressional and extensional episodes during the whole orogenic evolution, a model also favoured by Stephens et al. (2009) and Stephens and Jansson (2020). The latter divide the evolution into three overlapping tectonic cycles, at approximately $1.91-1.86 \mathrm{Ga}, 1.87-1.81 \mathrm{Ga}$, and $1.82-1.75 \mathrm{Ga}$, each involving magmatism and at least the two first also involving deformation and metamorphism.

\section{The Hedesunda granite complex}

The Hedesunda granite complex has the shape of a somewhat skewed rectangle extending E-W for about $40 \mathrm{~km}$ and $\mathrm{N}-\mathrm{S}$ about $20 \mathrm{~km}$, i.e. covering a surface area of ca 800 square kilometres (Fig. 1). It is surrounded by orthogneisses belonging to the early-orogenic 1.91-1.87 Ga GDG suite of Stephens et al. (2009), plus smaller areas with gneisses presumed to be of volcanic origin, 'migmatite granite', and mafic intrusions. The rocks of the Hedesunda complex vary from grey to pink or red in colour and are dominantly coarse-grained and porphyritic with large rectangular feldspar megacrysts. They show little or no signs of deformation, apart from some shearing along the northern boundary of the massif, with alignment of elongated feldspar megacrysts instead being of magmatic origin. The Hedesunda granite massif thus stands out from the surrounding earlyorogenic Svecofennian granitoids, which are pervasively deformed. However, it is also different from the late-orogenic (1.82-1.75 Ga) Svecofennian Granite-Pegmatite (GP) suite, since its rocks have more varied intermediate to felsic compositions.
This has led to considerable uncertainty about the age and tectonic position of the Hedesunda granite within the Svecofennian orogenic evolution. U-Pb dating (by TIMS) has given two sets of ages. A quartz monzodioritic sample close to the southern rim of the massif has given a $\mathrm{U}-\mathrm{Pb}$ zircon age of $1869 \pm 9 \mathrm{Ma}$ (Bergman et al. 2004), and a granitic sample close to its eastern rim a zircon + titanite age of $1863 \pm 16 \mathrm{Ma}$ (Stephens et al. 2009). On the other hand, Persson and Persson (1997) obtained a U-Pb zircon + titanite age of $1782 \pm 5$ Ma from a granite sample from the central part of the massif. This has led to a division of the granite complex into two different intrusions (Stephens et al. 2009), an older phase with an age of 1.87-1.86 Ga (Hedesunda I), only marginally younger than the surrounding GDG granitoids, but referred to as having a more alkalirich GSDG geochemistry, and a younger phase with an age of ca. $1.78 \mathrm{Ga}$ (Hedesunda II), tentatively assigned to the GP (Granite-Pegmatite) suite.

However, the geographic subdivision of the Hedesunda granite complex into these two different granite intrusions remains uncertain, at least in part reflecting bad exposure in this flat-lying and forested area. In their overview map of Bergslagen, Stephens et al. (2007) assigned almost the whole northwestern part of the massif (NW of Dalälven) to the younger GP phase, and the southeastern part to the older GSDG phase. However, on the more detailed 1:50,000 maps (Delin and Söderman 2005a, b; Bergman and Söderman 2005a, b), the younger phase is more restricted to two areas in the north-central and northwestern parts, largely based on geophysical interpretation, especially the aeromagnetic pattern. In the north-central part, there is a lowmagnetic circular area with an outer diameter of 9-11 km, interpreted as young Hedesunda II granite (dated in this area to $1782 \pm 5 \mathrm{Ma}$ ), which is surrounded by a high-magnetic rim (interpreted as old Hedesunda I granite) and has a high-magnetic area in its centre (also interpreted as old Hedesunda I granite; cf. Fig. 1). Further west, there is an elongated (ca $11 \mathrm{~km}$ long) low-magnetic area straddling the western boundary of the Hedesunda I massif, which was also interpreted as Hedesunda II granite.

To the east of the Hedesunda complex in Fig. 1, there are other granite massifs, such as the Månkarbo granite, which have also been assigned to the late-orogenic GP suite on geological maps, although they have not been dated or studied in any detail. Around Sevallbo at the southern margin of the Hedesunda complex, a special foliated granite variety, referred to as 'migmatite granite', was recognized during mapping by Delin and Söderman (2005a). Johansson and Stephens (2017) described it as a 'diffusely gneissic granodiorite', and dated it to $1880 \pm 4 \mathrm{Ma}$.

The purpose of the present study is to make a petrographic and geochemical investigation of the whole Hedesunda granite complex, and if possible use geochemical 
discrimination to help in delineating the two generations on the map, as well as determine their geochemical variation and discuss their petrogenesis and tectonic setting. Twentyeight samples covering most of the area in question, as far as the restricted outcrop allowed, have been obtained during field work. These have been studied petrographically and analysed geochemically for major and trace elements. Eighteen of these samples have also been analysed for their whole-rock $\mathrm{Sr}$ and $\mathrm{Nd}$ isotope composition, in order to determine the origin of their magma. In addition, selected zircons from the three previously dated rock samples have been reanalysed by SIMS (U-Th-Pb) in order to ascertain their age, and by LA-ICP-MS (Lu-Hf) in order to further clarify the magma origins. The new major and trace element data were complemented by earlier data obtained from the geochemical database of the Geological Survey of Sweden (SGU) from the same area, including samples assigned to one or the other of the two Hedesunda granite generations, as well as a few samples from neighbouring granitoid units.

\section{Field observations and sampling}

Differences in field appearance between the two granite generations are very subtle, and it is not strange that they were not separated in earlier mapping of the area (Sandegren and Asklund 1948; Sandegren and Lundegårdh 1949). Furthermore, no contacts have been observed, neither between the two granite generations nor with the surrounding bedrock units.

Rocks assigned to the older Hedesunda I generation on more recent maps (Bergman and Söderman 2005a, b; Delin and Söderman 2005a, b) are grey to pink in colour, mostly coarse and porphyritic with elongated rectangular K-feldspar megacrysts, sometimes displaying magmatic alignment (Fig. 2a-c). The variation in colour reflects a variation in composition, from intermediate to felsic. Mafic enclaves are sometimes observed (Fig. 2b). Smaller bodies with mafic compositions enclosed within the Hedesunda I granitoids have also been assigned to the same magmatic event (Sandegren and Asklund 1948; Rutanen and Andersson 2009) but have not been included in the present study. Pegmatitic and aplitic dykes are sometimes observed cutting the Hedesunda I rocks (Fig. 2d, e; cf. Sandegren and Lundegårdh 1949) and are believed to represent a late-stage phase of the same magmatic event.

Rocks assigned to the younger Hedesunda II generation are also mostly coarse grained and porphyritic, with pink to reddish colour (Fig. 2f, g, h). They are invariably of felsic composition. Felsic members of the Hedesunda I suite may however look very similar to Hedesunda II rocks, and so may more fine-grained and even-grained varieties of the two suites. A possible distinction between the porphyritic varieties of the two suites could be that the feldspar megacrysts in the Hedesunda I rocks are more distinct with a regular rectangular shape, whereas the Hedesunda II megacrysts seem to be more irregular in shape and thus be less distinct in appearance, at least in the circular body northeast of Ölbo. The Hedesunda II granite also lacks mafic enclaves as well as aplitic or pegmatitic dykes (Bergman and Söderman 2005a, b; Delin and Söderman 2005a, b).

In the present study, twenty-six samples of Hedesunda granitoid rocks were obtained from natural outcrops and roadcuts, with as large geographical spread over the area as the limited exposure allowed. Based on their field character and position in relation to the subdivision made on the recent SGU maps (Fig. 1), they were either assigned to the Hedesunda I (13 samples) or the Hedesunda II (13 samples) generation. Two foliated samples from the Hedesunda massif close to its northern margin (ÅJ17:26 and 27) were, in spite of their deformed nature, assigned to the Hedesunda I intrusive, based on their positions and petrographic character. One additional sample ( $\mathrm{AJ} 17: 07)$ from the southern margin of the massif was, however, based on field character and petrographic observations, considered part of the surrounding early-orogenic orthogneisses (Bergslagen GDG suite of Stephens et al. 2009), even though its location in Fig. 1 appears to be inside the Hedesunda massif. In addition, one aplitic dyke, crosscutting the Hedesunda I granite close to its eastern margin but believed to be related to it, was also sampled and analysed (ÅJ17:29), together with the surrounding coarse-grained granite (ÅJ17:28).

Sample localities are marked in Fig. 1, and a list of samples with GPS coordinates is provided in Table 1. Photographs of hand specimen from each of the twenty-eight samples are provided in Online Resource 5.

\section{Analytical methods}

\section{Petrography and geochemistry}

Polished thin sections were studied in the petrographic microscope in order to determine the mineralogy and texture of the investigated samples. In order to estimate the approximate proportions of major minerals within these samples, powdered whole-rock samples were analysed by $\mathrm{XRD}$, since point counting in single $3 \times 2 \mathrm{~cm}$ thin sections of such coarse-grained rocks are not likely to give representative results. X-ray powder diffraction data were recorded on a PANalytical $\mathrm{X}^{\prime} \mathrm{Pert}^{3}$ Powder diffractometer equipped with an $X^{\prime}$ 'celerator silicon strip detector and operated at $40 \mathrm{~mA}$ and $45 \mathrm{kV}(\mathrm{Cu}$ K $\alpha$-radiation, $\lambda=1.5406 \AA)$. Peak positions were determined with the X'Pert HighScore Plus 4.6 software, and Braggs peak positions (in $2 \theta$ space) were 

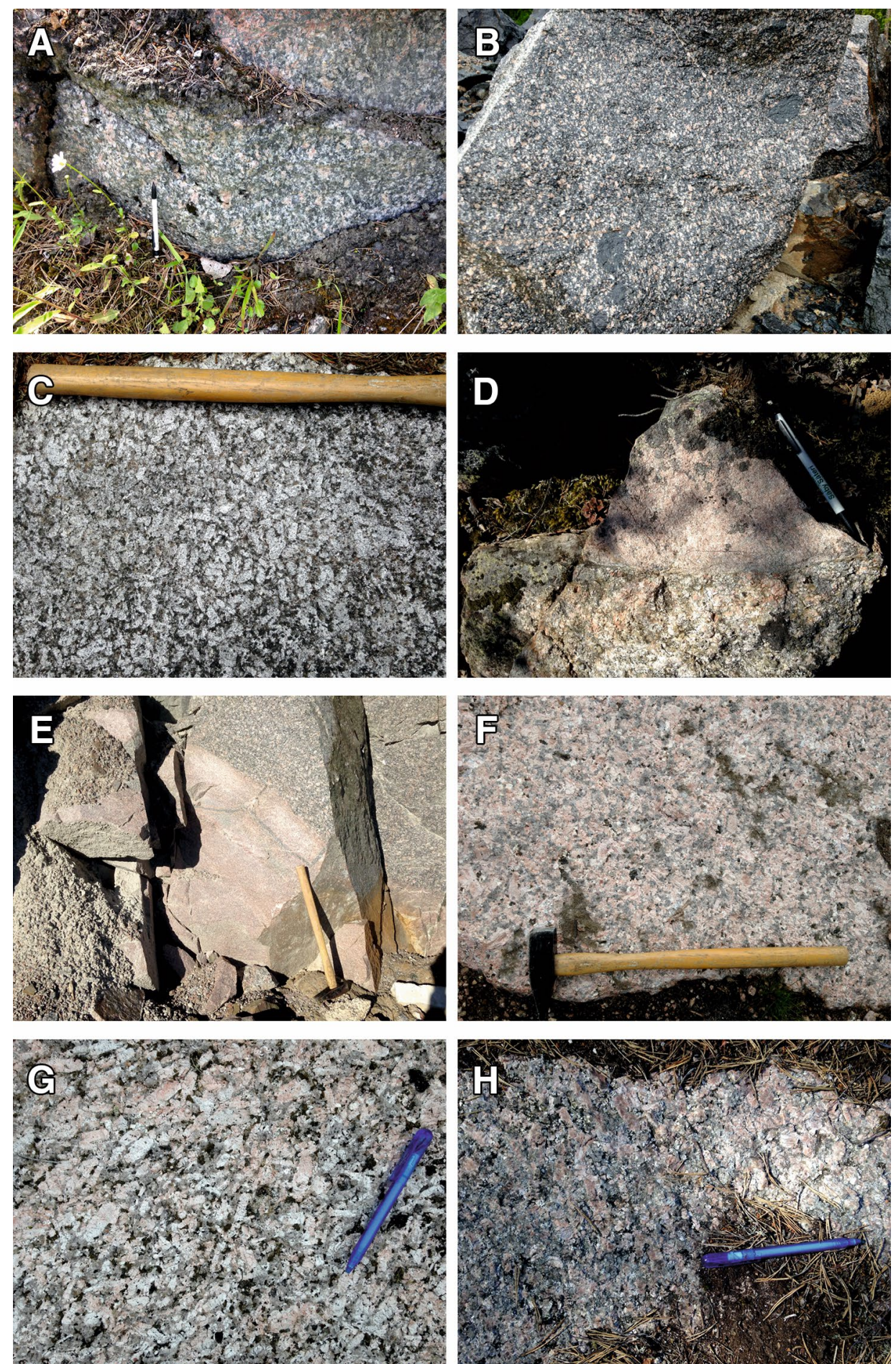

Fig. 2 Field photographs of Hedesunda I and II rocks. a Typical porphyritic Hedesunda I granite of granodioritic composition in roadcut southeast of Söderfors (sample locality AJ17:05). Pencil $15 \mathrm{~cm}$. b Boulder of intermediate Hedesunda I granite with mafic enclaves. c Close-up of Hedesunda I granite at Fäbodsjön (close to sampling locality AJ17:17). d Aplitic dyke in Hedesunda I granite (sample locality $\AA$ J 17:28 and 29). e Aplitic dyke in Hedesunda I granite,
Strömsberg quarry (close to sample locality $̊ \mathrm{~J} 17: 30$ ). f Typical reddish coarse-porphyritic Hedesunda II granite north of Bredforsen in Dalälven (sample locality AJ17:09). Hammer shaft $50 \mathrm{~cm}$. g Hedesunda II granite northeast of Ölbo, close-up of slightly weathered surface (sample locality $\AA$ J 17:13 and LP94:1). h Close-up of Hedesunda II granite from the western massif (sample locality ÅJ17:21) 
Table 1 List of samples with sample coordinates, Hedesunda granitoid complex, east-central Sweden

\begin{tabular}{|c|c|c|c|}
\hline Sample no. & Map sheet & Latitude/longitude (GPS) & Rock type \\
\hline ÅJ17:01 & $12 \mathrm{H} \mathrm{NO}$ & $60^{\circ} 18^{\prime} 59^{\prime \prime} \mathrm{N} / 17^{\circ} 23^{\prime} 14^{\prime \prime} \mathrm{E}$ & Hedesunda I granite \\
\hline ÅJ17:02 & $12 \mathrm{H} \mathrm{NO}$ & $60^{\circ} 24^{\prime} 34^{\prime \prime} \mathrm{N} / 17^{\circ} 19^{\prime} 46^{\prime \prime} \mathrm{E}$ & Hedesunda I granite \\
\hline ÅJ17:03 & $12 \mathrm{H} \mathrm{NO}$ & $60^{\circ} 23^{\prime} 45^{\prime \prime} \mathrm{N} / 17^{\circ} 17^{\prime} 16^{\prime \prime} \mathrm{E}$ & Hedesunda I granite \\
\hline ÅJ17:04 & $12 \mathrm{H} \mathrm{NO}$ & $60^{\circ} 23^{\prime} 32^{\prime \prime} \mathrm{N} / 17^{\circ} 16^{\prime} 49^{\prime \prime} \mathrm{E}$ & Hedesunda I granite \\
\hline ÅJ17:05 & $12 \mathrm{H} \mathrm{NO}$ & $60^{\circ} 22^{\prime} 21^{\prime \prime} \mathrm{N} / 17^{\circ} 16^{\prime} 17^{\prime \prime} \mathrm{E}$ & Hedesunda I granite \\
\hline ÅJ17:06 & $12 \mathrm{H} \mathrm{NO}$ & $60^{\circ} 23^{\prime} 03^{\prime \prime} \mathrm{N} / 17^{\circ} 15^{\prime} 10^{\prime \prime} \mathrm{E}$ & Hedesunda I granite \\
\hline ÅJ17:07 & $12 \mathrm{H} \mathrm{NO}$ & $60^{\circ} 20^{\prime} 11^{\prime \prime} \mathrm{N} / 17^{\circ} 12^{\prime} 42^{\prime \prime} \mathrm{E}$ & Gneissic granite (GDG suite) \\
\hline ÅJ17:08 & $12 \mathrm{H} \mathrm{NO}$ & $60^{\circ} 23^{\prime} 57^{\prime \prime} \mathrm{N} / 17^{\circ} 12^{\prime} 44^{\prime \prime} \mathrm{E}$ & Hedesunda II granite \\
\hline ÅJ17:09 & $13 \mathrm{H} \mathrm{SO}$ & $60^{\circ} 25^{\prime} 15^{\prime \prime} \mathrm{N} / 17^{\circ} 11^{\prime} 34^{\prime \prime} \mathrm{E}$ & Hedesunda II granite \\
\hline ÅJ17:10 & $13 \mathrm{H} \mathrm{SO}$ & $60^{\circ} 26^{\prime} 30^{\prime \prime} \mathrm{N} / 17^{\circ} 11^{\prime} 50^{\prime \prime} \mathrm{E}$ & Hedesunda II granite \\
\hline ÅJ17:11 & $13 \mathrm{H} \mathrm{SO}$ & $60^{\circ} 26^{\prime} 30^{\prime \prime} \mathrm{N} / 17^{\circ} 11^{\prime} 35^{\prime \prime} \mathrm{E}$ & Hedesunda II granite \\
\hline ÅJ17:12 & $13 \mathrm{H} \mathrm{SO}$ & $60^{\circ} 26^{\prime} 27^{\prime \prime} \mathrm{N} / 17^{\circ} 11^{\prime} 33^{\prime \prime} \mathrm{E}$ & Hedesunda II granite \\
\hline ÅJ17:13 ${ }^{\mathrm{a}}$ & $13 \mathrm{H} \mathrm{SV}$ & $60^{\circ} 25^{\prime} 13^{\prime \prime} \mathrm{N} / 17^{\circ} 03^{\prime} 44^{\prime \prime} \mathrm{E}$ & Hedesunda II granite \\
\hline ÅJ17:16 & $12 \mathrm{~N} \mathrm{NV}$ & $60^{\circ} 23^{\prime} 27^{\prime \prime} \mathrm{N} / 16^{\circ} 55^{\prime} 53^{\prime \prime} \mathrm{E}$ & Hedesunda I granite \\
\hline ÅJ17:17 & $13 \mathrm{H} \mathrm{SV}$ & $60^{\circ} 27^{\prime} 08^{\prime \prime} \mathrm{N} / 16^{\circ} 58^{\prime} 00^{\prime \prime} \mathrm{E}$ & Hedesunda I granite \\
\hline ÅJ17:18 & 13H SV & $60^{\circ} 28^{\prime} 52^{\prime \prime} \mathrm{N} / 16^{\circ} 56^{\prime} 56^{\prime \prime} \mathrm{E}$ & Hedesunda II granite \\
\hline ÅJ17:19 & $13 \mathrm{H} \mathrm{SV}$ & $60^{\circ} 28^{\prime} 57^{\prime \prime} \mathrm{N} / 16^{\circ} 57^{\prime} 45^{\prime \prime} \mathrm{E}$ & Hedesunda I granite \\
\hline ÅJ17:20 & $13 \mathrm{H} \mathrm{SV}$ & $60^{\circ} 28^{\prime} 42^{\prime \prime} \mathrm{N} / 16^{\circ} 57^{\prime} 14^{\prime \prime} \mathrm{E}$ & Hedesunda II granite \\
\hline ÅJ17:21 & $13 \mathrm{H} \mathrm{SV}$ & $60^{\circ} 25^{\prime} 50^{\prime \prime} \mathrm{N} / 16^{\circ} 49^{\prime} 08^{\prime \prime} \mathrm{E}$ & Hedesunda II granite \\
\hline ÅJ17:22 & $13 \mathrm{H} \mathrm{SV}$ & $60^{\circ} 26^{\prime} 18^{\prime \prime} \mathrm{N} / 16^{\circ} 50^{\prime} 14^{\prime \prime} \mathrm{E}$ & Hedesunda II granite \\
\hline ÅJ17:23 & $13 \mathrm{H} \mathrm{SV}$ & $60^{\circ} 26^{\prime} 06^{\prime \prime} \mathrm{N} / 16^{\circ} 43^{\prime} 58^{\prime \prime} \mathrm{E}$ & Hedesunda II granite \\
\hline ÅJ17:24 & 13H SV & $60^{\circ} 26^{\prime} 10^{\prime \prime} \mathrm{N} / 16^{\circ} 42^{\prime} 58^{\prime \prime} \mathrm{E}$ & Hedesunda II granite \\
\hline ÅJ17:25 & $13 \mathrm{H} \mathrm{SV}$ & $60^{\circ} 27^{\prime} 36^{\prime \prime} \mathrm{N} / 16^{\circ} 44^{\prime} 11^{\prime \prime} \mathrm{E}$ & Hedesunda II granite \\
\hline ÅJ17:26 & $13 \mathrm{H} \mathrm{SO}$ & $60^{\circ} 29^{\prime} 33^{\prime \prime} \mathrm{N} / 17^{\circ} 19^{\prime} 02^{\prime \prime} \mathrm{E}$ & Hedesunda I granite (foliated) \\
\hline ÅJ17:27 & $13 \mathrm{H} \mathrm{SO}$ & $60^{\circ} 28^{\prime} 59^{\prime \prime} \mathrm{N} / 17^{\circ} 26^{\prime} 59^{\prime \prime} \mathrm{E}$ & Hedesunda I granite (foliated) \\
\hline ÅJ17:28 & $13 \mathrm{H} \mathrm{SO}$ & $60^{\circ} 25^{\prime} 01^{\prime \prime} \mathrm{N} / 17^{\circ} 33^{\prime} 36^{\prime \prime} \mathrm{E}$ & Hedesunda I granite \\
\hline ÅJ17:29 & $13 \mathrm{H} \mathrm{SO}$ & $60^{\circ} 25^{\prime} 01^{\prime \prime} \mathrm{N} / 17^{\circ} 33^{\prime} 36^{\prime \prime} \mathrm{E}$ & Light red aplite dyke \\
\hline ÅJ17:30 & $13 \mathrm{H} \mathrm{SO}$ & $60^{\circ} 25^{\prime} 00^{\prime \prime} \mathrm{N} / 17^{\circ} 32^{\prime} 47^{\prime \prime} \mathrm{E}$ & Hedesunda I granite \\
\hline
\end{tabular}

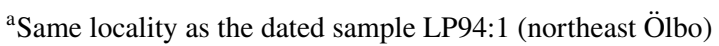

${ }^{\mathrm{b}}$ Aplite dyke cutting the $\AA \mathrm{J}$ 17:28 granite

${ }^{\mathrm{c}}$ Same locality as the dated sample MBS000131A (Strömsberg quarry) corrected against an external Si metal standard (NIST SRM 640).

The diffractograms were subsequently refined using Rietveld refinement (with X'Pert HighScore Plus 4.6 software), where the following parameters were refined: (1) scale factor, (2) background coefficients (flat background and 5 coefficients), (3) specimen displacement, (4) unit cells for all phases (to account for varying chemistry in solid-solution minerals), and 5) preferred orientations. All diffractograms were refined to residual peaks of less than $0.5 \%$. The results are reported in Table 2.

Powdered whole-rock samples were also sent to Acme Analytical Labs. (Bureau Veritas), Vancouver, Canada, and analysed for major elements by ICP emission spectrometry and for trace elements (including rare earth elements) by
ICP mass spectrometry. The results are reported in Online Resource 2.

In order to complement my own data set, a set of samples with coordinates and geochemical data from the relevant area encompassing the Hedesunda granite complex and its closest surroundings was obtained from the rock chemistry database of the Geological Survey of Sweden (SGU). These samples consist of two subsets of data: samples obtained and analysed as part of the SGU mapping program $(n=27)$, and samples obtained and analysed as part of an unpublished geochemical study of the area by Björn Öhlander (Luleå Technical University; $n=41$ ) that had been incorporated within the SGU database. Based on their geographic position and their classification and character, as could be deduced from the database, these samples were either assigned to the Hedesunda I type $(n=31)$, the Hedesunda II type $(n=14)$, or some of the surrounding rock units (early-orogenic GDG 
orthogneisses, $n=5$; Sevallbo migmatite granite, $n=6$; lateorogenic granite at Månkarbo or east of Tierp, $n=4$; and mafic intrusive rocks related to the Hedesunda complex; $n=2)$. The latter samples have also been plotted in some diagrams for comparative purposes. Seven of the SGU samples were discarded because of uncertainty of which rock suite they should be assigned to. The two Hedesunda mafic samples from SGU were complemented by three analyses of similar mafic rocks published by Rutanen and Andersson (2009).

Plotting of the SGU sample data on the same plots as the data obtained in the present study unfortunately caused a substantial increase in scatter which to some extent blurs the results, although the data generally agree and support each other. In part, this scatter may simply reflect that with an increased number of data points, there will be more variation and more outliers. However, it may also reflect that these samples were analysed by different laboratories at different occasions, in some cases perhaps with older and less precise methods. Not all analyses included all trace elements, so for many of the trace element plots only a smaller number of the SGU samples could be used. Furthermore, some of the SGU samples were discovered to include erroneous Eu and $\mathrm{Yb}$ values (identical to the Er and Lu values, respectively), so these had to be discarded from REE diagrams and other plots including those elements

\section{Sr and Nd isotope analysis}

Eighteen of the twenty-eight rock samples were selected for $\mathrm{Sr}$ and $\mathrm{Nd}$ isotope analysis, eight representing the Hedesunda I granite and ten the Hedesunda II variety. The analytical work was carried out at the Department of Geosciences of the Swedish Museum of Natural History. Between 80 and $180 \mathrm{mg}$ of rock powder from each sample was dissolved in a 10:1 mixture of concentrated $\mathrm{HF}$ and $\mathrm{HNO}_{3}$, together with a mixed ${ }^{147} \mathrm{Sm}^{-150} \mathrm{Nd}$ spike, in Teflon capsules at $205^{\circ} \mathrm{C}$ for a few days. After evaporation and redissolution in $6 \mathrm{M} \mathrm{HCl}$, the solutions were passed through TRU-spec columns for separation of $\mathrm{Sr}$ and REE as a group. Strontium was further purified using Sr-spec columns. From the REE solutions, Sm and Nd were separated using Ln-spec columns (Pin and Zalduegui 1997).

Unspiked Sr, and spiked Sm and Nd were loaded on double Re filaments and analysed on a Thermo Triton thermal ionization mass spectrometer (TIMS) in static mode. Corrections for background, spike addition ( $\mathrm{Sm}$ and $\mathrm{Nd}$ ), interference, and fractionation were carried out as reported in the footnotes of Tables 3 and 4. The results are reported in Table $3(\mathrm{Sr})$ and Table $4(\mathrm{Nd})$, together with the results on the NBS SRM987 Sr standard and the La Jolla Nd standard.

\section{U-Th-Pb SIMS analysis}

Separated zircon concentrates from the same samples previously analysed by ID-TIMS (isotope dilution thermal ionization mass spectrometry; Persson and Persson 1997; Bergman et al. 2004; Stephens et al. 2009) were obtained from Per-Olof Persson at the Department of Geosciences, Swedish Museum of Natural History. Reasonably well-shaped and clear crystals were selected by handpicking from the non-magnetic 74-106 $\mu \mathrm{m}$ size fraction of all three samples, mounted in epoxy and polished in half to reveal their inner structure. This structure was studied and documented both in reflected and transmitted light in a petrographic microscope, and in CL (cathodoluminescence) using a Philips XL30 ESEM-FEG scanning electron microscope prior to analysis. Subsequent to the SIMS analysis, the analysed zircon crystals and spot locations were documented in reflected and transmitted light (combined), CL (better quality combined SEM-CL images using the Philips scanning electron microscope), and by BSE (back-scatter electron) on a FEI Quanta 650 FEG scanning electron microscope. BSE images with spot locations and obtained ${ }^{207} \mathrm{~Pb} /{ }^{206} \mathrm{~Pb}$ ages and $\mathrm{Th} / \mathrm{U}$ ratios of all analysed zircons are provided in Online Resources 6-8, and similar SEM-CL images in Online Resources 9-11.

The U-Th- $\mathrm{Pb}$ isotopic analysis (with $20 \mu \mathrm{m}$ spots) was carried out at the Nordsim facility at the Swedish Museum of Natural History in Stockholm, using a Cameca 1280 Secondary Ion Mass Spectrometer (SIMS). The analytical procedure followed Whitehouse et al. (1999) and Whitehouse and Kamber (2005), with the calibration scheme of Jeon and Whitehouse (2015). The 91500 zircon standard with an accepted age of $1065 \mathrm{Ma}$ (Wiedenbeck et al. 1995) was used as a reference. Common $\mathrm{Pb}$ was assumed to have been introduced principally during preparatory work and corrections were made for the present-day composition of common $\mathrm{Pb}$ using the values provided by Stacey and Kramers (1975). The U-Th-Pb analytical data are presented in Online Resource 1. Age calculations were carried out using the Isoplot/Ex 4.15 (Ludwig 2003). Ages are reported in the text with $2 \sigma$ uncertainties, excluding decay-constant errors.

\section{Lu-Hf LA-ICP-MS analysis}

$\mathrm{Lu}-\mathrm{Hf}$ isotope composition was analysed from the majority of the zircon grains analysed for $\mathrm{U}-\mathrm{Th}-\mathrm{Pb}$, using a $\mathrm{Nu}$ Plasma II Multicollector ICP-MS coupled to an ESI NWR193UC excimer laser ablation system at the Vegacenter facility of the Swedish Museum of Natural History in Stockholm. Details of the analytical procedure have been outlined by Robinson et al. (2018). All ${ }^{176} \mathrm{Hf} /{ }^{177} \mathrm{Hf}$ ratios were normalized to the primary reference zircon Mud Tank (Woodhead and Hergt 2005). For quality control, zircon reference materials Temora, Plesovice, and FC1 were analysed 
alongside the samples and the results were compared to their reported values. ${ }^{176} \mathrm{Hf} /{ }^{177} \mathrm{Hf}$ for these zircons were $0.282663 \pm 0.000047(n=11,2 \sigma), 0.282477 \pm 0.000019$ $(n=10,2 \sigma)$, and $0.282172 \pm 0.000040(n=10,2 \sigma)$, respectively.

The analytical results are reported in Online Resource 3. Positions of the analysed ca $50 \mu \mathrm{m}$ spots and the obtained initial $\varepsilon_{\mathrm{Hf}}$ values have been indicated on the BSE and CL images of respective zircon in Online Resources 6-11.

\section{$\mathrm{U}-\mathrm{Pb}$ age determination results}

\section{Sample MBS000131A, Strömsberg quarry (eastern part of the Hedesunda complex)}

Sample MBS000131A comes from the Strömsberg quarry in the eastern part of the Hedesunda complex northeast of Tierp (coordinates $60^{\circ} 25^{\prime} 02^{\prime \prime} \mathrm{N} / 17^{\circ} 32^{\prime} 46^{\prime \prime} \mathrm{E}$ ). According to the original description, it is a coarse-grained granitic to quartz monzonitic rock, which has been intruded by finegrained granite and pegmatite (Stephens et al. 2009). Zircon and titanite were separated and analysed by ID-TIMS at the Swedish Museum of Natural History, with the results being reported in an appendix to Stephens et al. (2009). A discordia line encompassing all three analysed zircon fractions and three titanite fractions yielded an upper intercept age of $1863 \pm 16 \mathrm{Ma}$ (when forced through $0 \pm 400 \mathrm{Ma}$ ), considered to represent the magmatic crystallization age. Four additional titanite fractions plotted to the left of the discordia line with ${ }^{207} \mathrm{~Pb} /{ }^{206} \mathrm{~Pb}$ ages down to $1811 \mathrm{Ma}$, indicating postmagmatic disturbance.

The zircon crystals handpicked from this sample for the present SIMS analysis were of somewhat variable quality. They were dominantly prismatic but somewhat rounded, varying from relatively clear to dark, turbid, and fractured. Magmatic (oscillatory) zonation was visible in the light microscope, as well as core-like structures and overgrowths, which, however, seemed to represent different magmatic pulses when seen in CL and BSE, rather than inheritance and metamorphism, respectively.

In BSE, the investigated zircons mostly showed coarse and faint zoning in various shades of grey. Some of the zircon crystals, especially the very elongated $\mathrm{Zr} 07$ and $\mathrm{Zr} 11$, have narrow BSE-dark metamict zones (presumably U rich) parallel to the magmatic growth zonation (BSE images in Online Resource 6). In CL, the zircons show much more variation than in BSE. Textures range from homogeneous CL-grey (especially in zircon interiors), thinly CL-zoned (oscillatory magmatic zonation), striped appearance in very elongated crystals to irregular and patchy (CL images in Online Resource 9). Thin CL-dark metamict zones are sometimes seen, but less so and not as clearly as in BSE. A few zircons $(\mathrm{Zr} 24,30,38)$ have a discontinuous CL-dark outer rim that may be of metamorphic origin. In $\mathrm{Zr} 02,17,25$ and 39 (and Zr19 in BSE), this CL-dark (presumably U rich) rim grows out into larger irregular areas in part replacing the original magmatic zircon. In BSE, the corresponding areas are bright, but not as sharply delineated and well seen as in CL.

Twelve spots in twelve zircons were analysed by SIMS. Six of these spots, ranging from concordant to $10 \%$ normal discordant, form a discordia line with an upper intercept of $1862 \pm 7 \mathrm{Ma}$ (lower intercept at $276 \pm 220 \mathrm{Ma}$, MSWD 0.77; Fig. 3a). Forcing the discordia line through the origin will change the upper intercept age only marginally to $1858 \pm 6 \mathrm{Ma}$, identical to the weighted average ${ }^{207} \mathrm{~Pb} /{ }^{206} \mathrm{~Pb}$ age of those six points (MSWD 1.7). The $1862 \pm 7$ Ma upper intercept age, which is almost identical to the previous $\mathrm{U}-\mathrm{Pb}$ zircon + titanite TIMS age, is taken as the best estimate of the magmatic crystallization age of the Hedesunda granite in the Strömsberg quarry. It is noteworthy that this age is identical to the metamorphic U-Pb monazite age of $1863 \pm 1 \mathrm{Ma}$ from a highly foliated grey migmatitic gneiss along the eastern margin of the Hedesunda complex ca. $2 \mathrm{~km}$ east of the Strömsberg quarry reported by Johansson and Stephens (2017).

The remaining six spot analysis, however, fall to the left of the discordia with a degree of discordance ranging from -3 to $-17 \%$ and ${ }^{207} \mathrm{~Pb} /{ }^{206} \mathrm{~Pb}$ ages ranging from 1814 to $1701 \mathrm{Ma}$ (Online Resource 1, Fig. 3a). This is similar to the pattern of the previous $\mathrm{U}-\mathrm{Pb}$ titanite analyses described above, and could be taken to indicate metamorphic recrystallization. However, all of these spots are in texturally magmatic zircon and have magmatic $\mathrm{Th} / \mathrm{U}$ ratios similar to the spots falling along the discordia line $(\mathrm{Th} / \mathrm{U}$ of $0.40-0.82$; Online Resource 1, Fig. 3a). In the Th vs. U diagram (Fig. 3a), all twelve analyses fall on a similar magmatic differentiation trend. Also, no metamorphic or magmatic activity younger than ca. $1780 \mathrm{Ma}$ is known in the area, making the youngest ${ }^{207} \mathrm{~Pb} /{ }^{206} \mathrm{~Pb}$ ages down to $1700 \mathrm{Ma}$ difficult to explain by metamorphic resetting. These apparently disturbed spots seem to have hit fractures, or in some cases (Zr11, Zr13) metamict zones, and may have undergone a combination of ancient and more recent $\mathrm{Pb}$ loss, that, however, left their Th-U systems intact. These spots have thus been classified as 'magmatic/altered' in Online Resource 1. Areas in $\mathrm{Zr02}, 17,19,25$, and 39 that seem to consist of secondary replaced zircon in CL or BSE (cf. Zr02 and 25 in Online Resources 6 and 9) were only observed after the SIMS analysis and were hence unfortunately not analysed. Nevertheless, they are an additional sign of post-magmatic disturbance in these zircons. 


\section{Sample HLD020767A, south of Sevallbo (southern part of the Hedesunda complex)}

Sample HLD020767A is a quartz monzodioritic rock (Delin and Söderman 2005a) from the lobe of the Hedesunda granite complex extending south of Sevallbo at its southern margin. Zircon was separated and analysed by ID-TIMS at the Swedish Museum of Natural History, with the results being reported in abstract form as ca. $1.87 \mathrm{Ga}$ by Bergman et al. (2004). The age was subsequently specified to $1869 \pm 9 \mathrm{Ma}$ by Delin and Söderman (2005a) and Stephens et al. (2009), but without giving any additional analytical details. According to P-O Persson (pers. comm. 2019), this age was based on the upper intercept of a discordia through four slightly discordant zircon fractions and forced through the origin.

The zircons handpicked from this sample for SIMS analysis were generally of superior quality compared to those from the Strömsberg quarry, being prismatic and relatively clear, with oscillatory zoning visible in transmitted light.

In BSE, the analysed zircons mostly show a coarse and faint zoning in various shades of grey, similar to the previous sample (BSE images in Online Resource 7). Some fractures are seen at the surface, but less than in that sample, and no metamict bands or patches. The zircons in the HLD sample are also clearer and less turbid than the zircons in the previous sample. There are no inherited cores seen, nor any metamorphic rims or replacement structures.

As in the previous sample, much more detail is seen in the CL images than in the BSE images from the present zircons. They dominantly show magmatic oscillatory zoning in various shades of CL-grey or CL-bright, sometimes with more homogeneous CL-grey central areas of grains (probably an effect of not cutting across the centre of a crystal, but along one growth zone), and occasionally a bit more irregular and patchy appearance (CL images in Online Resource 10). In very elongated zircon crystals, the oscillatory zoning may give a striped appearance both in CL and BSE. As in BSE, there are neither any inherited cores nor any metamorphic rims or replacement structures seen, but they all seem to have a simple magmatic history.

Sixteen spots in sixteen zircons were analysed (Online Resource 1). In keeping with their simple magmatic appearance, fifteen of them plot concordantly and yield a concordia age of $1865 \pm 4$ Ma (MSWD 0.34; Fig. 3b), within error identical to the previously obtained TIMS age, and interpreted to date the magmatic crystallization of this rock. The $\mathrm{Th} / \mathrm{U}$ ratios fall between 0.45 and 0.92 , with the Th and $\mathrm{U}$ concentrations following a magmatic differentiation trend similar to that in the previous sample (Fig. 3b).

\section{Sample LP94:1, northeast of Ölbo (north-central part of the Hedesunda complex)}

Sample LP94:1 is a coarse-grained granite from a roadcut $1250 \mathrm{~m} \mathrm{NE}$ of the village Ölbo in the north-central part of the Hedesunda complex, within the low-magnetic circular anomaly that would subsequently be designated as a separate intrusion (Delin and Söderman 2005b), here referred to as Hedesunda II granite. Zircons and titanite were separated and analysed by ID-TIMS at the Swedish Museum of Natural History, with the result being published by Persson and Persson (1997) together with major and trace element data on the sample. One concordant titanite fraction and three (out of four) discordant zircon fractions together defined a discordia with an upper intercept age at $1782 \pm 5 \mathrm{Ma}$, taken by the authors as the magmatic crystallization age.

Zircons handpicked for the present SIMS analysis were prismatic but somewhat rounded, varying from relatively clear to dark and turbid, with magmatic (oscillatory) zonation visible in transmitted light. As reported by Persson and Persson (1997), cores were relatively common. Some of the cores may represent an early magmatic phase, but most of them are rounded and most likely inherited, sometimes with radiating fractures in the surrounding mantle, indicating expansion due to metamictization.

In BSE, the selected and analysed zircon grains had various shades of grey, without any very obvious zonation (BSE images in Online Resource 8). BSE-dark zones and patches were, however, observed in many of the zircons. With the exception of the core in $\mathrm{Zr} 44$, these areas do not show up in CL as being dark and are hence probably not metamict, but instead U-poor (none of these areas were analysed for $\mathrm{U}-\mathrm{Th}-\mathrm{Pb}$ by SIMS). The very distinct BSE-dark core in $\mathrm{Zr} 44$ is surrounded by radiating fractures and dark also in $\mathrm{CL}$, and hence metamict.

In CL there is more variation. Some zircon grains show distinct oscillatory magmatic zonation which is mostly CL-bright (U-poor), whereas others (also of magmatic appearance) are homogeneously CL-grey. Still others have irregular and patchy CL-patterns, especially those with inherited cores, suggesting later disturbances (CL images in Online Resource 11). Several zircon grains have CL-dark (or dark grey) patches and irregular areas, but with the exception of the $\mathrm{Zr} 44$ core, these do not match with the BSE-dark areas in the same grains, but rather with BSE-bright areas, suggesting that these are not metamict areas, but U-rich irregular zones, possibly affected by post-magmatic alteration.

In summary, these are the texturally most complex Hedesunda zircons out of the three samples investigated, since they both contain abundant inherited cores, a dominant magmatic phase, and parts of zircon crystals that appear to have undergone some sort of post-magmatic alteration with irregular U-rich (BSE-bright and CL-dark) or U-poor 
(BSE-dark) areas, even though the rock as such is non-metamorphic. None of the latter areas have been analysed, so the age of this alteration is unknown. Among the analysed spots $(n=19)$, the $U$ and Th contents are also highly variable and in part very high, the most extreme spot (the core 44a) having almost $12,000 \mathrm{ppm} \mathrm{U}$ and more than $7800 \mathrm{ppm}$ Th.

Nineteen spots in sixteen zircon crystals were analysed (Online Resource 1). Four of these spots (10a, 13a, 44a, 48a; Online Resources 1, 8 and 11) represent visible cores, out of which at least the former three were rounded and metamict and interpreted as inherited. All of these were more or less discordant due to metamictization and did not give any useful age information. A fifth spot (32) in the centre of a seemingly normal magmatic zircon yielded a reversely discordant ${ }^{207} \mathrm{~Pb} /{ }^{206} \mathrm{~Pb}$ age of $1855 \pm 9 \mathrm{Ma}$ and may hence represent inheritance from the Hedesunda I phase. This spot also had a deviating, much higher $\mathrm{Th} / \mathrm{U}$ ratio $(0.96)$ than the rest of the magmatic zircon (0.26-0.55).

The remaining fourteen spots are all texturally magmatic, but still show some scatter and variable amounts of discordance, partly reflecting high $\mathrm{Th}$ and $\mathrm{U}$ concentrations. Nine out of them, however, yield a concordia age of $1787 \pm 4 \mathrm{Ma}$ (MSWD 1.02; Fig. 3c). An identical upper intercept age can be obtained from twelve concordant or discordant points, with lower intercept around $500 \mathrm{Ma}$ and MSWD 0.83, whereas eight spots yield a weighted average ${ }^{207} \mathrm{~Pb} /{ }^{206} \mathrm{~Pb}$ age of $1785 \pm 3 \mathrm{Ma}$ (MSWD 0.54 ). The concordia age of $1787 \pm 4 \mathrm{Ma}$ is taken as the best estimate of the crystallization age of the granite northeast of Ölbo.

\section{Summary of $\mathrm{U}-\mathrm{Pb}$ dating}

The newly obtained U-Pb SIMS ages are within error identical to the previous TIMS ages from the same samples and thus confirm the earlier ages. Both sets of age data have been inserted on the geological map shown in Fig. 1, together with recently published U-Pb zircon or monazite SIMS ages from immediately surrounding rock units (Johansson and Stephens 2017).

It is thus clear that the Hedesunda granitoid complex is a composite intrusion, consisting of an older Hedesunda I suite with an age of ca $1865 \mathrm{Ma}$, and a younger Hedesunda II granite with an age of ca $1785 \mathrm{Ma}$, i.e. an age difference of ca 80 million years. The Hedesunda I suite is only marginally younger than the surrounding ca 1.91-1.87 Ga earlyorogenic GDG orthogneisses, which, however, have not been dated in the immediate vicinity. It shows little or none of the pervasive regional deformation that has affected the surrounding GDG suite, although its magmatic age overlaps with the 1875-1850 Ma range inferred for early Svecofennian metamorphism in east-central Sweden (Johansson and Stephens 2017 and references therein).

The age of the Hedesunda I suite is also marginally younger than the $1880 \pm 4 \mathrm{Ma}$ Sevallbo migmatite
Fig. 3 a U-Pb concordia diagram for SIMS analyses from sample MBS000131A from Strömsberg quarry. Shaded ellipses are included in the age calculation. In the diagrams of $\mathrm{Th} / \mathrm{U}$ vs. ${ }^{207} \mathrm{~Pb} /{ }^{206} \mathrm{~Pb}$ age, and Th (ppm) vs. $\mathrm{U}(\mathrm{ppm})$ to the right, the dark symbols represent points included in the age calculation. $\mathbf{b} \mathrm{U}-\mathrm{Pb}$ concordia diagram for SIMS analyses from sample HLD020767A from south of Sevallbo. Shaded ellipses are included in the age calculation; small coloured ellipse marks the concordia age ( $2 \sigma$ error). In the diagrams of $\mathrm{Th} / \mathrm{U}$ vs. ${ }^{207} \mathrm{~Pb} /{ }^{206} \mathrm{~Pb}$ age, and $\mathrm{Th}(\mathrm{ppm})$ vs. $\mathrm{U}$ (ppm) to the right, the dark symbols represent points included in the age calculation (all but no. 01). c U-Pb concordia diagram for SIMS analyses from sample LP94:1 northeast of Ölbo. Shaded ellipses are included in the age calculation. In the diagrams of Th/U vs. ${ }^{207} \mathrm{~Pb} /{ }^{206} \mathrm{~Pb}$ age, and $\mathrm{Th}(\mathrm{ppm})$ vs. $\mathrm{U}$ (ppm) to the right, the dark symbols represent points included in the age calculation

granite at its southern rim, and a nearby felsic dyke dated at $1872 \pm 2$ Ma (Johansson and Stephens 2017). The Sevallbo migmatite granite is also more deformed and should probably be regarded as a variety of the surrounding GDG orthogneisses, rather than an early phase of the Hedesunda granitoid complex. The nearby felsic dyke, on the other hand, may be an early precursor of the Hedesunda I magmatism.

The Hedesunda II granite at 1785 Ma falls within the wide age range of late-orogenic Svecofennian GP intrusives within the Bergslagen lithotectonic unit (ca 1.85-1.75 Ga; compilation in Stephens et al. 2009, see also later discussion), as well as penecontemporaneous GSDG intrusives within the Transscandinavian Igneous Belt (1.81-1.78 Ga, op. cit.).

\section{Petrography}

The mineralogy and texture of all twenty-eight rock samples used for whole-rock geochemistry have been studied in thin section, with some representative microphotographs shown in Fig. 4. Furthermore, the approximate modal proportions of the major minerals in all samples were determined through XRD analysis of whole-rock powders. The results are listed in Table 2 and illustrated in Fig. 5, with the samples being subdivided and sorted into inferred Hedesunda I and Hedesunda II granites (13 each), plus one sample of the surrounding GDG orthogneiss ( $\mathrm{AJ} 17: 07)$, and one aplite dyke sample (ÅJ17:29).

All Hedesunda samples are dominated by quartz, K-feldspar, and plagioclase in variable proportions, plus some amphibole and/or biotite. The Hedesunda I samples show more variation in their modal compositions, with quartz content ranging from 17 to $39 \%$, and up to $19 \%$ mafic minerals in the intermediate members of this suite. The Hedesunda II samples are more homogeneous, with quartz ranging from 30 to $40 \%$, and only a couple of percent of amphibole and biotite. In some Hedesunda I or Hedesunda II samples, the mafic minerals only occur as minor constituents, and in a few cases, no amphibole at all was detected in the XRD analysis, possibly due to heavy alteration, as observed in thin section. 

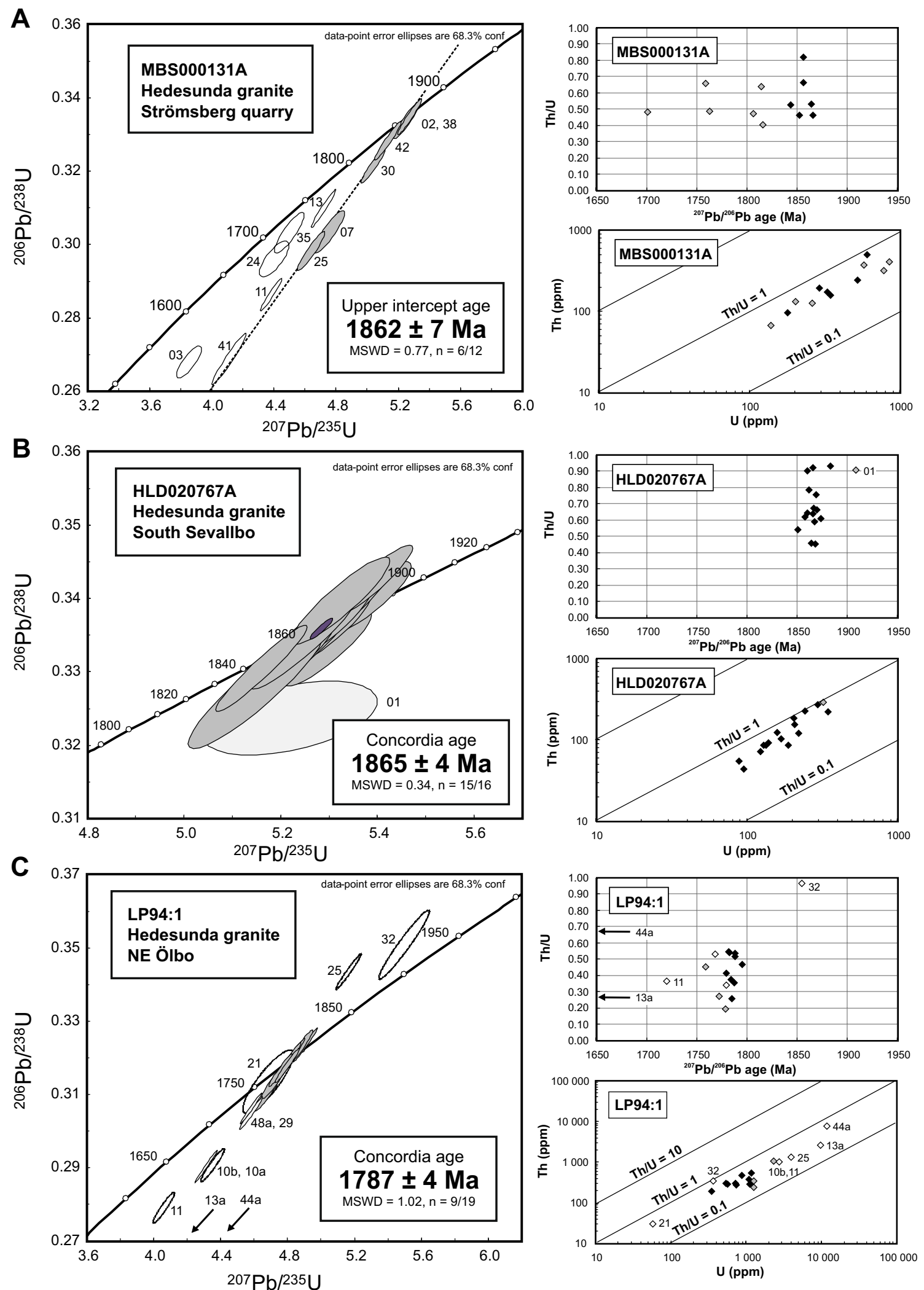
Fig. 4 Microphotographs of selected thin sections. All photos are at the same magnification (1 mm scale bar). The photos in the left-hand column are with parallel nicols, the ones to the right show the same area with crossed nicols. a Sample ÅJ17:01 Hedesunda I granodiorite. b Sample ÅJ17:03 Hedesunda I granite. c Sample ÅJ17:05 Hedesunda I granodiorite. d Sample ÅJ17:13 Hedesunda II granite. e Sample ÅJ17:20 Hedesunda II granite. Mineral abbreviations: $q z$ quartz, plag plagioclase, $k f s p$ K-feldspar, amph amphibole, $b i$ biotite, $t i$ titanite, all allanite, opq opaques

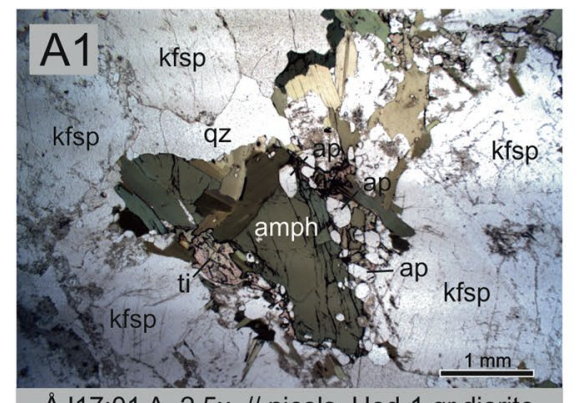

ÂJ17:01 A, 2.5x, // nicols. Hed-1 gr.diorite

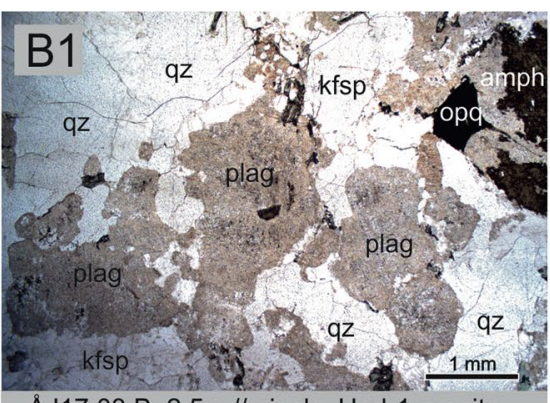

ÅJ17:03 B, 2.5x, // nicols. Hed-1 granite
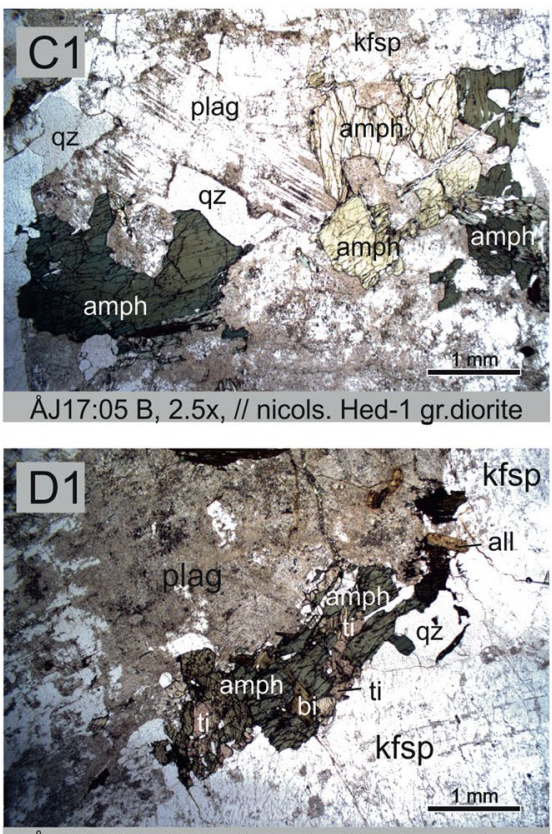

ÅJ17:13 A, 2.5x, // nicols. Hed-2 granite

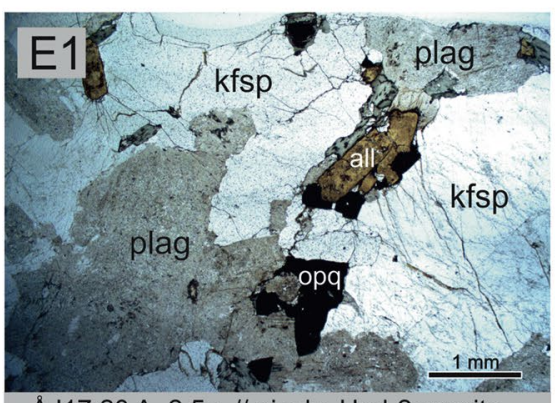

ÅJ17:20 A, 2.5x, // nicols. Hed-2 granite
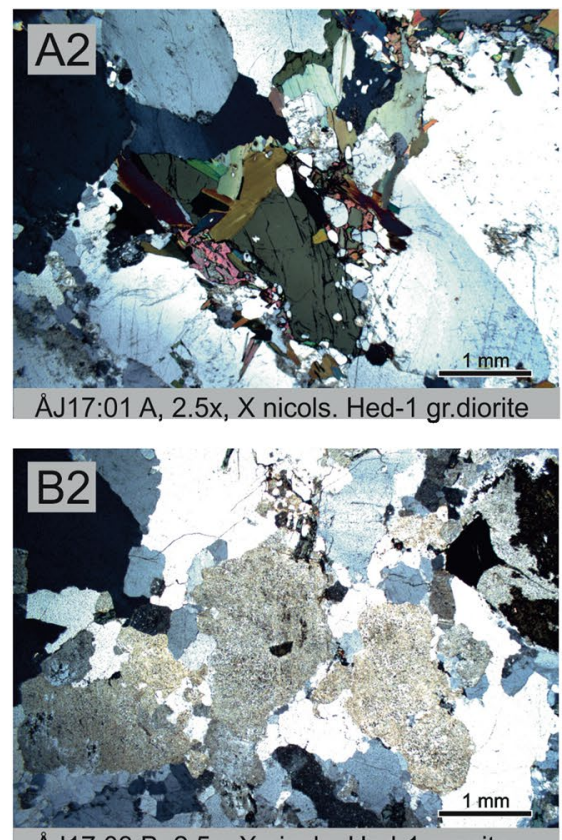

ÃJ17:03 B, 2.5x, X nicols. Hed-1 granite
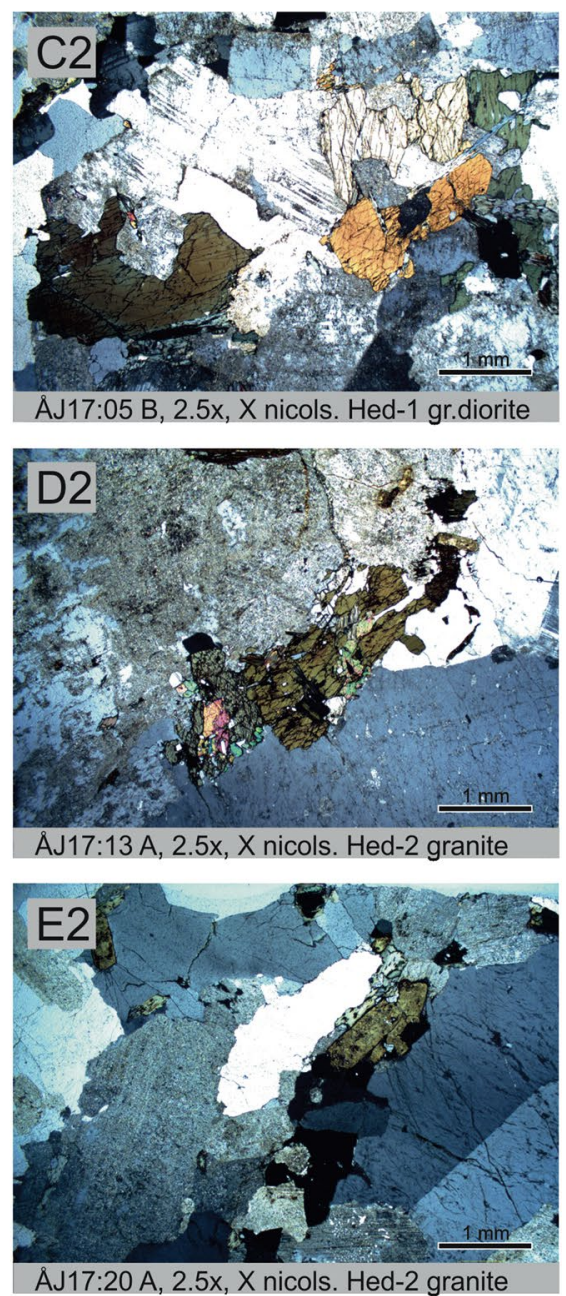
The aplitic dyke sample has a modal composition similar to the more felsic Hedesunda I samples, or the Hedesunda II ones. The single GDG orthogneiss sample stands out by containing very little K-feldspar and no amphibole but only biotite (plus minor oxides) as mafic phase (Table 2, Fig. 5a).

If the proportions of quartz, K-feldspar, and plagioclase are plotted in a QAP diagram of Streckeisen (1976), the Hedesunda I samples range from granodiorite to monzogranite in composition, the Hedesunda II samples are purely monzogranitic, the aplite dyke sample is also monzogranitic, and the single sample of GDG orthogneiss plots as tonalite (Fig. 5b).

When it comes to minor or accessory constituents, titanite, apatite, and oxides were noted in most thin sections, zircon in about half of them, and pyrite in a few samples (Table 2). Titanite is a rather frequent constituent both in the Hedesunda I and in many of the Hedesunda II samples, as aggregates together with amphibole and biotite, or as 1-2 mm large euhedral single grains. Epidote is mentioned as a minor constituent in these rocks in the map descriptions by Sandegren and Asklund (1948) and Sandegren and Lundegårdh (1949) and presumably occurs in many of these samples, although it was not observed in the studied thin sections. Allanite is also mentioned by these authors, and was observed here as up to $2 \mathrm{~mm}$ long well-shaped euhedral brown crystals (but often heavily altered) in almost all of the Hedesunda II samples, but in only two if the rocks classified as Hedesunda I granite. Although perhaps not diagnostic in separating these granite types, it is thus more typical for the Hedesunda II variety.

The amphibole is green to blue-green in colour; biotite ranges from pale brown to brownish green under the microscope. Both minerals are variably altered, biotite more so than amphibole, and has been grouped together with secondary chlorite as shown in Table 2 and Fig. 5a. According to the map descriptions (Sandegren and Asklund 1948; Sandegren and Lundegårdh 1949), the K-feldspar megacrysts in the Hedesunda rocks consists of microcline or microcline perthite. However, in the present investigation, only limited microcline twinning was seen. It is normally quite fresh, unlike the plagioclase which appears heavily altered. In several of the Hedesunda II samples, there is a very clear distinction between fresh and unaltered K-feldspar and heavily altered plagioclase in the thin sections, the latter sometimes containing fine brown hematite dusting. The presence of hematite dusting in the plagioclase is also pointed out by Sandegren and Lundegårdh (1949). From this, it thus appears that much of the red colouring, at least in the Hedesunda II variety, is due to hematite dusting in the plagioclase rather than in the K-feldspar. In the Hedesunda I rocks, the plagioclase alteration is more patchy and irregular, leaving some areas relatively intact.

\section{Major and trace element geochemistry}

Major and trace element data, including rare earth elements, from the investigated samples are reported in Online Resource 2 and illustrated in Figs. 6, 7, 8 and 9. In most of these figures, data points from the geochemistry database of SGU from the same area have also been plotted. These include both samples classified as Hedesunda I and II, as well as some samples from the surrounding granitoids, as discussed above. Furthermore, five samples of mafic rocks believed to be related to the Hedesunda I massif, two from the SGU database and three from Rutanen and Andersson (2009), have also been included in some of these plots.

\section{Major and trace element classification}

In the Total Alkali-Silica (TAS) diagram of Middlemost (1994; Fig. 6a), the Hedesunda I samples range from diorite through tonalite and granodiorite to granite, falling on the subalkaline side of the alkaline-subalkaline division line of Irvine and Baragar (1971). The associated mafic samples plot as gabbro or gabbroic diorite. The Hedesunda II samples all plot as true granite. It is noteworthy that the Hedesunda I suite thus follows a tonalitic GDG (granite-diorite-gabbro) trend similar to the surrounding early-orogenic orthogneisses, and not the more syenitic GSDG trend that was proposed for it by Stephens et al. (2009) in their overview of the Bergslagen lithotectonic unit. However, they did not include any geochemical samples from the Hedesunda I rocks in their GSDG group. In the AFM diagram of Irvine and Baragar (1971), the Hedesunda I and II samples follow distinctly separate differentiation trends, which both, however, are calc-alkaline (Fig. 6b). In the P-Q-diagram of Debon and Le Fort (1983), the Hedesunda I samples trend from quartz monzodiorite through granodiorite and adamellite to granite, while the Hedesunda II samples are purely granitic (Fig. 6c).

In the trace element classification diagram of Winchester and Floyd (1977), there is a clear division between the Hedesunda I and Hedesunda II samples, the latter plotting at higher $\mathrm{Zr} / \mathrm{TiO}_{2}$ ratios (Fig. 6d). In the MALI diagram (Modified Alkali-Lime Index; Frost et al. 2001), the Hedesunda I samples mainly follow a calc-alkalic trend, while the Hedesunda II samples range from alkali-calcic to calc-alkalic or even calcic at the high-silica end of the spectrum (Fig. 6e).

In terms of $\mathrm{K}_{2} \mathrm{O}$ versus $\mathrm{SiO}_{2}$ (Peccerillo and Taylor 1976; see Fig. 7), the Hedesunda I samples plot as high-K calc-alkaline, whereas the Hedesunda II samples trend into the shoshonitic field. In the A/NK versus A/CNK diagram (Shand 1943, Maniar and Piccoli 1989), the Hedesunda I samples range from metaluminous to peraluminous, whereas the Hedesunda II samples are almost purely peraluminous, 


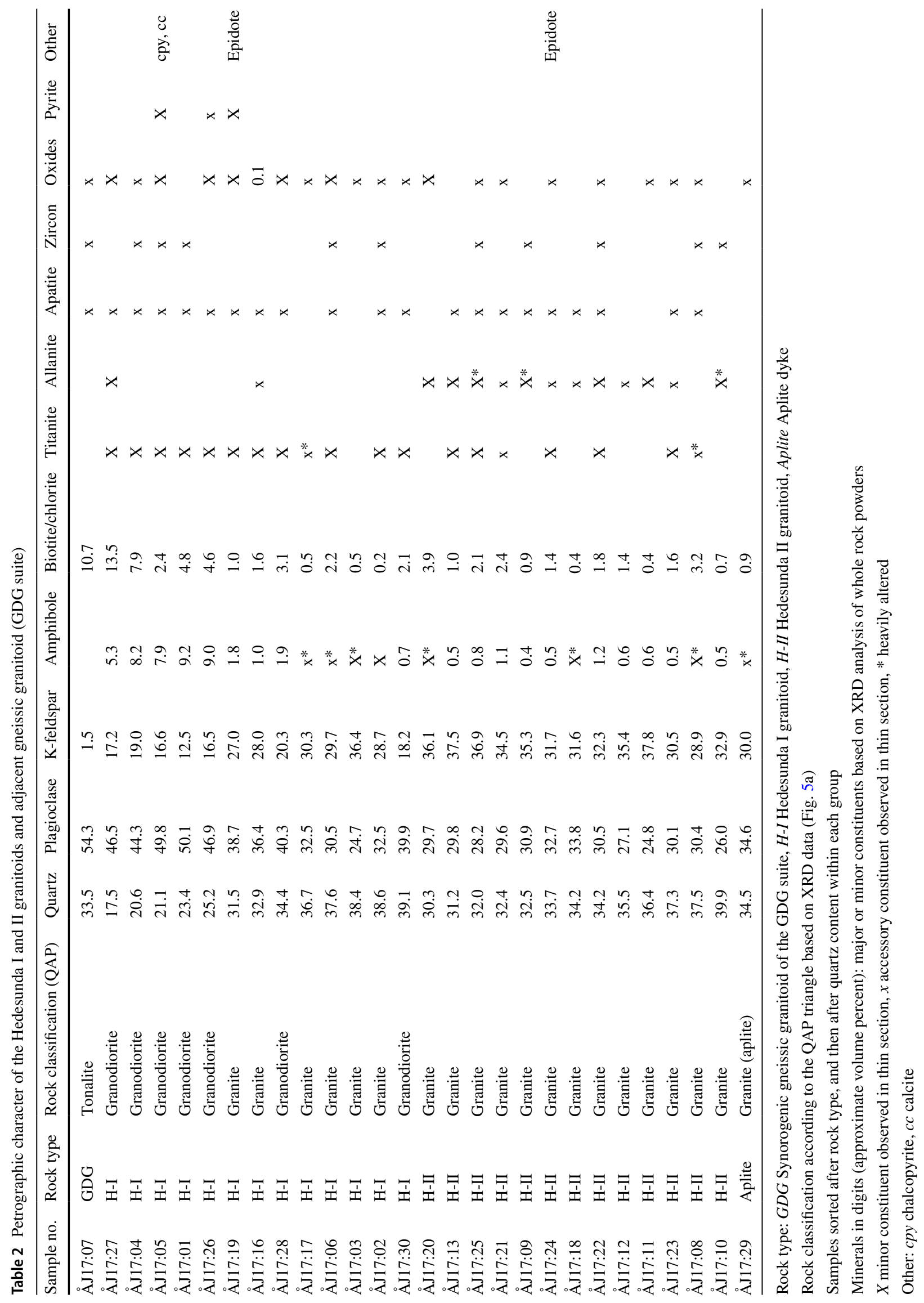


Fig. 5 a Modal mineral composition calculated from XRD analyses of powdered whole-rock samples. For each rock group, the samples have been ordered from the lowest to the highest quartz content. GDG=one sample of the surrounding GDG suite orthogneisses (ÅJ17:07); $\mathrm{Apl}=$ one sample of an aplite dyke (ÅJ17:29) cutting the Hedesunda I granite (sample ÅJ17:28). b. The same modal data plotted in the QAP (quartz-alkali feldspar-plagioclase) diagram of Streckeisen (1976). The Hedesunda I samples range from granodiorite to monzogranite in composition; the Hedesunda II samples are purely monzogranitic
A

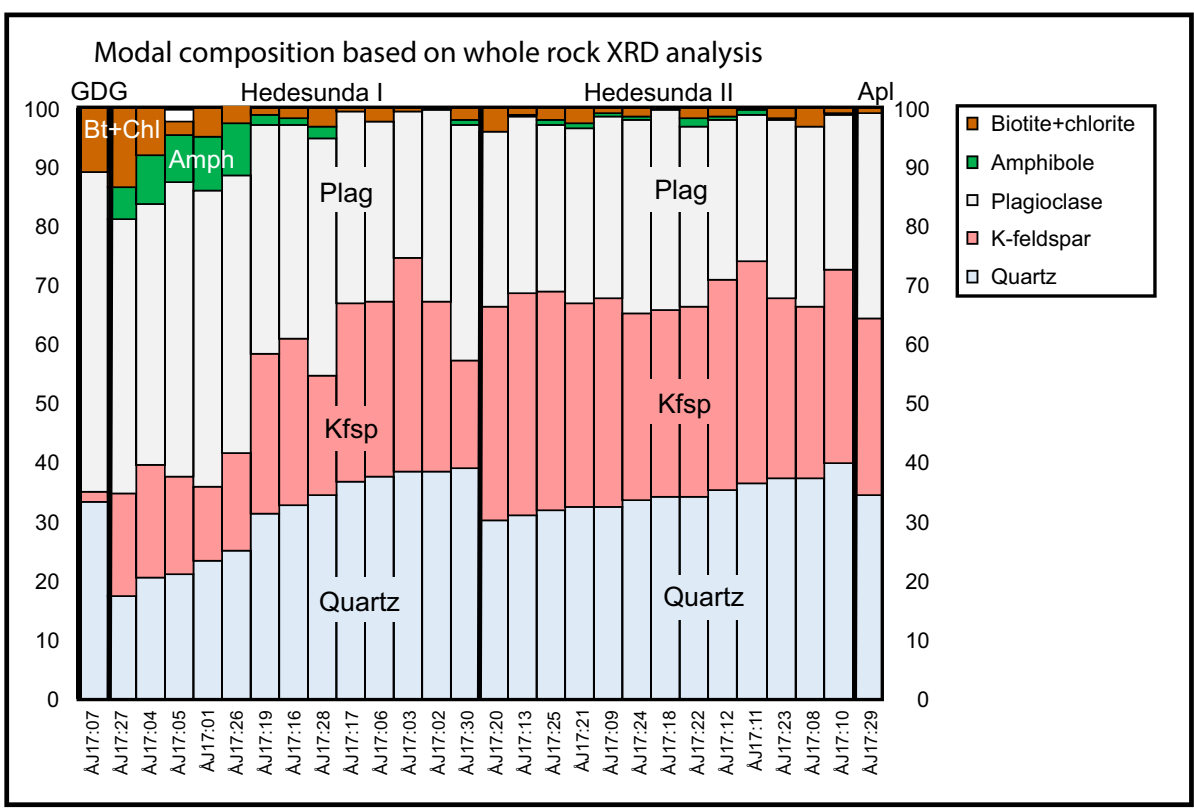

B

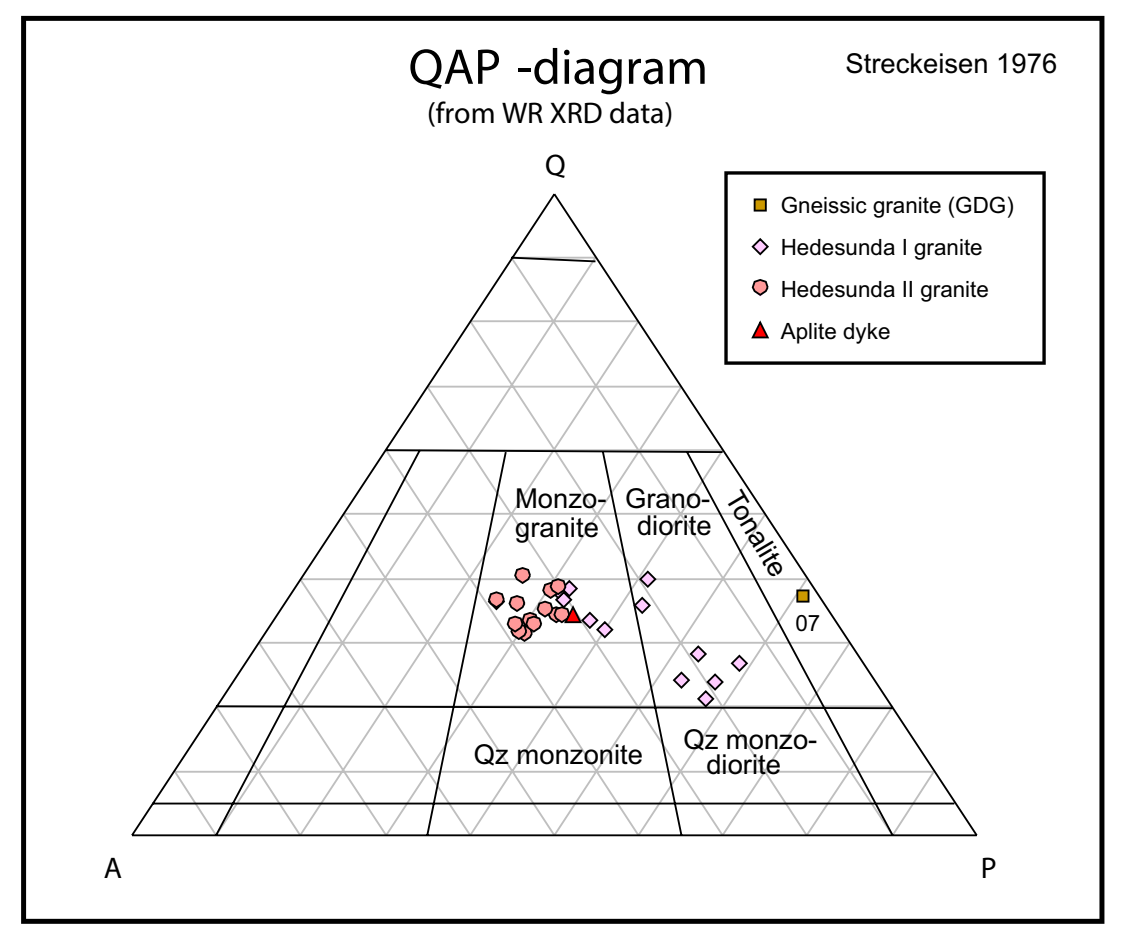

but still mainly I type (A/CNK $<1.1$; Fig. 6 f). In terms of $\mathrm{FeO} /(\mathrm{FeO}+\mathrm{MgO})$ versus $\mathrm{SiO}_{2}$ (Frost et al. 2001), the Hedesunda I samples are magnesian and the Hedesunda II samples are ferroan (Fig. 6g).

\section{Differentiation trends in Harker diagrams}

When it comes to major elements versus silica (Fig. 7), the Hedesunda I and II granitoids follow similar differentiation trends, although the Hedesunda II granitoids have a much more narrow range of $\mathrm{SiO}_{2}(70-78 \mathrm{wt} \%)$ than the Hedesunda I granitoids (55-76 wt $\%$, SGU samples included). Most of the major elements decrease with the increasing $\mathrm{SiO}_{2}$ as normal, $\mathrm{Na}_{2} \mathrm{O}$ follows a slightly curved trend, and $\mathrm{K}_{2} \mathrm{O}$ increases, but with substantial scatter. However, there are subtle differences in the trends for $\mathrm{FeO}, \mathrm{MgO}, \mathrm{CaO}, \mathrm{Na}_{2} \mathrm{O}$, and $\mathrm{K}_{2} \mathrm{O}$ between Hedesunda I and II samples that are more clearly seen in Fig. 6e and g. It is noteworthy that the five 
A

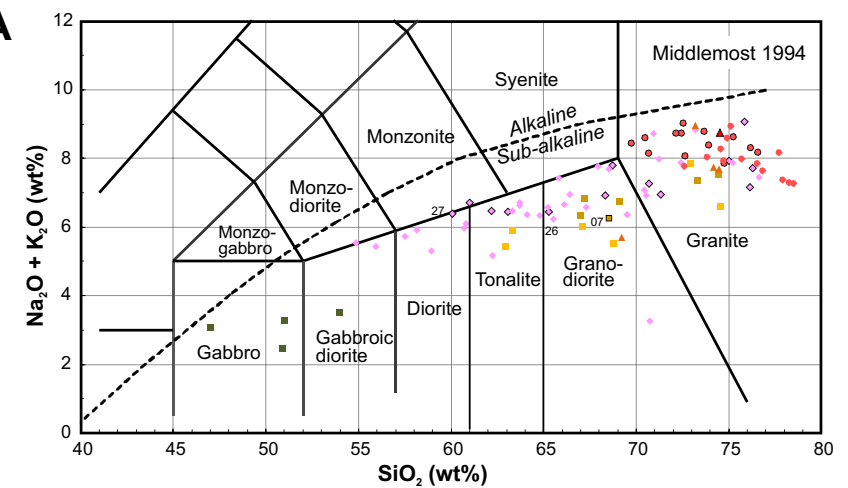

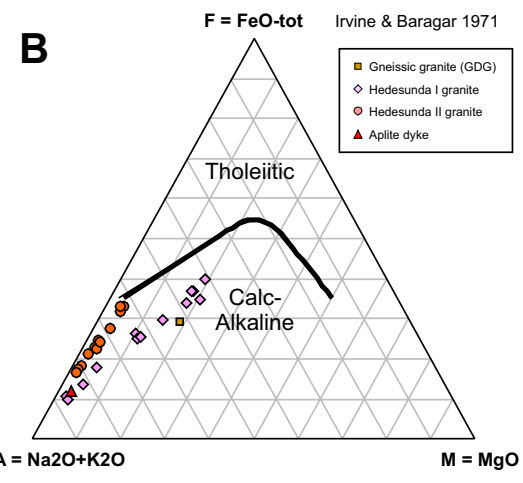

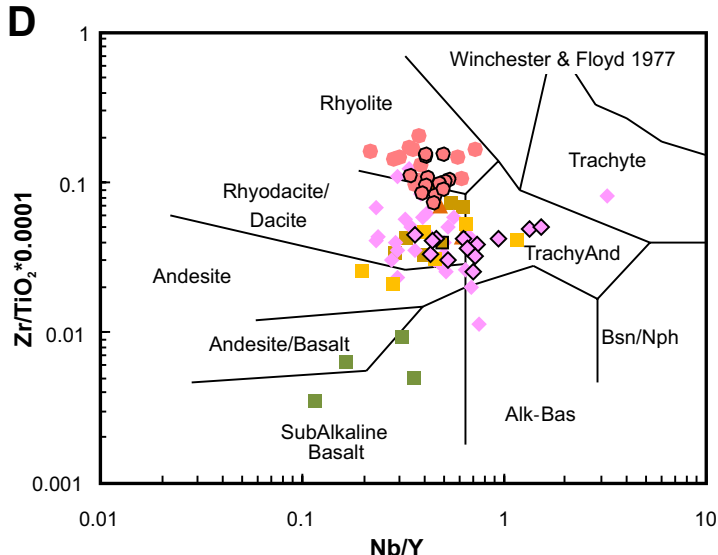

$\mathbf{F}$

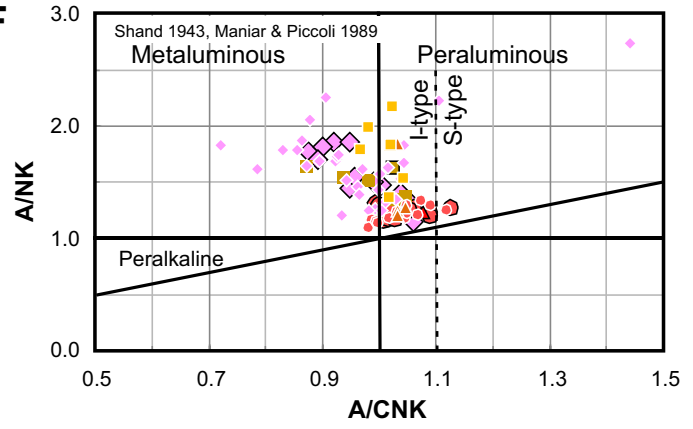

口 GDG rocks (this study)

$\diamond$ Hedesunda I (this study)

- Hedesunda II (this study)

- Aplite dyke (this study)

- GDG rocks (SGU samples)

- Hedesunda I (SGU samples)

- Hedesunda II (SGU samples)

$\triangle$ Månkarbo etc. (SGU samples)

- Sevallbo (SGU samples)

- Mafic rocks (SGU samples)

- Mafic rocks (R\&A 2009)

$\mathrm{SiO}_{2}(\mathrm{wt} \%)$

Fig. 6 Rock classification diagrams from chemical analyses. a Total alkali-silica (TAS) diagram after Middlemost (1994). b AFM diagram after Irvine and Baragar (1971). c P-Q-diagram after Debon and Le Fort (1983). to tonalite, $g d$ granodiorite, $a d$ adamellite, $q d$ quartz diorite, qmzd quartz monzodiorite, qmz quartz monzonite, qsy quartz syenite, $g b$ gabbro, $m z g b$ monzogabbro, $m z$ monzonite, $s y$ syenite. d Classification diagram after Winchester and Floyd (1977). e Modified alkali-lime index (MALI) after Frost et al. (2001). f A/NK (molar $\mathrm{Al}_{2} \mathrm{O}_{3} /\left(\mathrm{Na}_{2} \mathrm{O}+\mathrm{K}_{2} \mathrm{O}\right)$ ) vs. $\mathrm{A} / \mathrm{CNK}\left(\right.$ molar $\mathrm{Al}_{2} \mathrm{O}_{3} /\left(\mathrm{CaO}+\mathrm{Na}_{2} \mathrm{O}+\mathrm{K}_{2} \mathrm{O}\right)$ ) plot after Shand (1943) and Maniar and Piccoli (1989). g $\mathrm{FeO} /(\mathrm{FeO}+\mathrm{MgO})$ vs. $\mathrm{SiO}_{2}$ diagram after Frost et al. (2001). In most diagrams, both samples analysed in this study (symbols with solid outlines) and samples from the SGU database plus three mafic rock samples from Rutanen and Andersson (2009) (symbols without outlines) have been included; in diagrams $\mathbf{b}$ and $\mathbf{c}$ (AFM and P-Q diagrams) only the samples analysed in this study are plotted for clarity. In diagram a (TAS diagram), the gneissic GDG sample and the two gneissic Hedesunda I samples have been labelled with the last digits in their sample number 

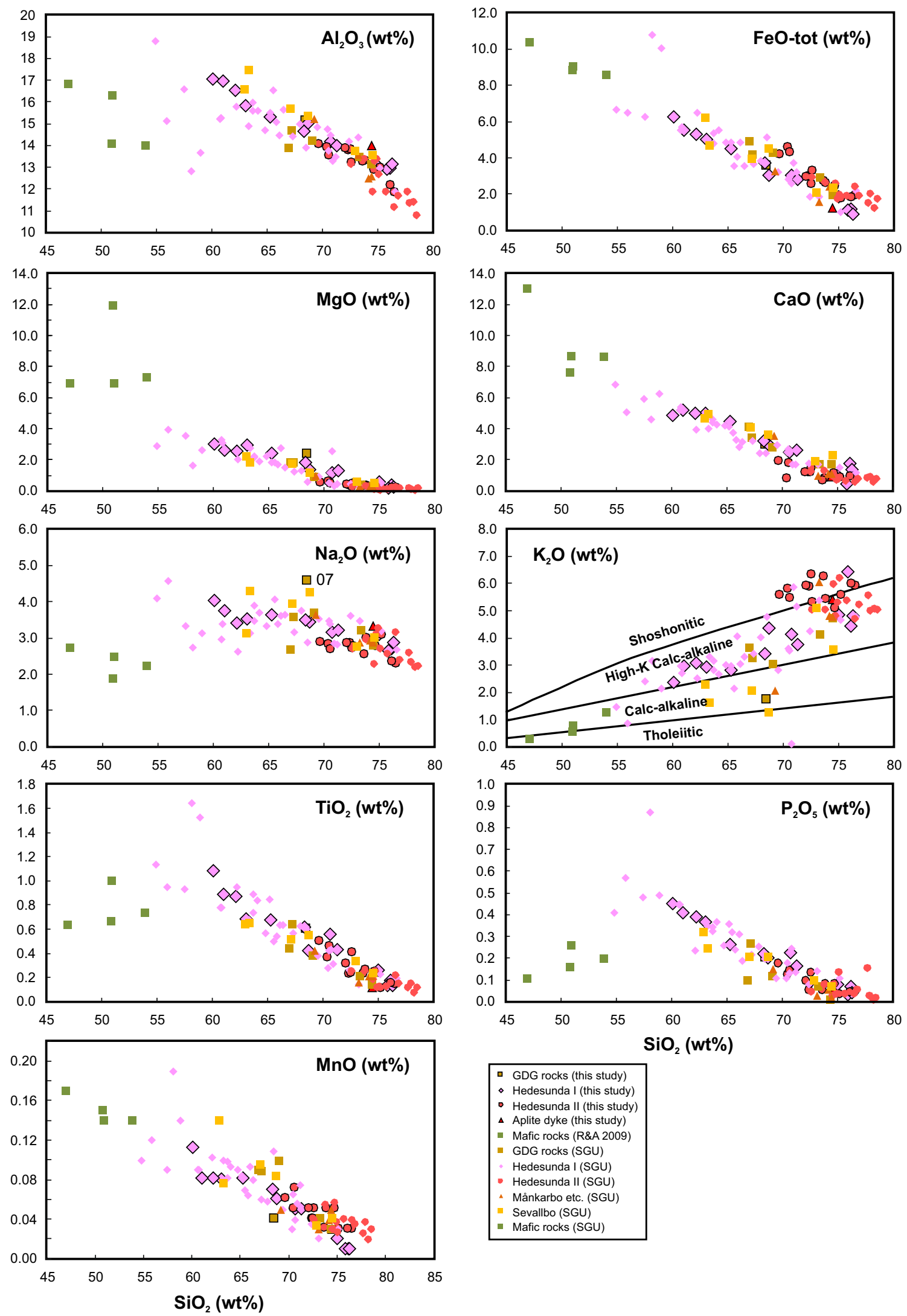

Fig. 7 Major elements versus $\mathrm{SiO}_{2}$ for all studied samples from the Hedesunda complex and immediately surrounding rock units [this study, SGU database samples, and mafic rock samples from Rutanen

and Andersson (2009)]. Division lines in the $\mathrm{K}_{2} \mathrm{O}$ vs. $\mathrm{SiO}_{2}$ diagram after Peccerillo and Taylor (1976) 

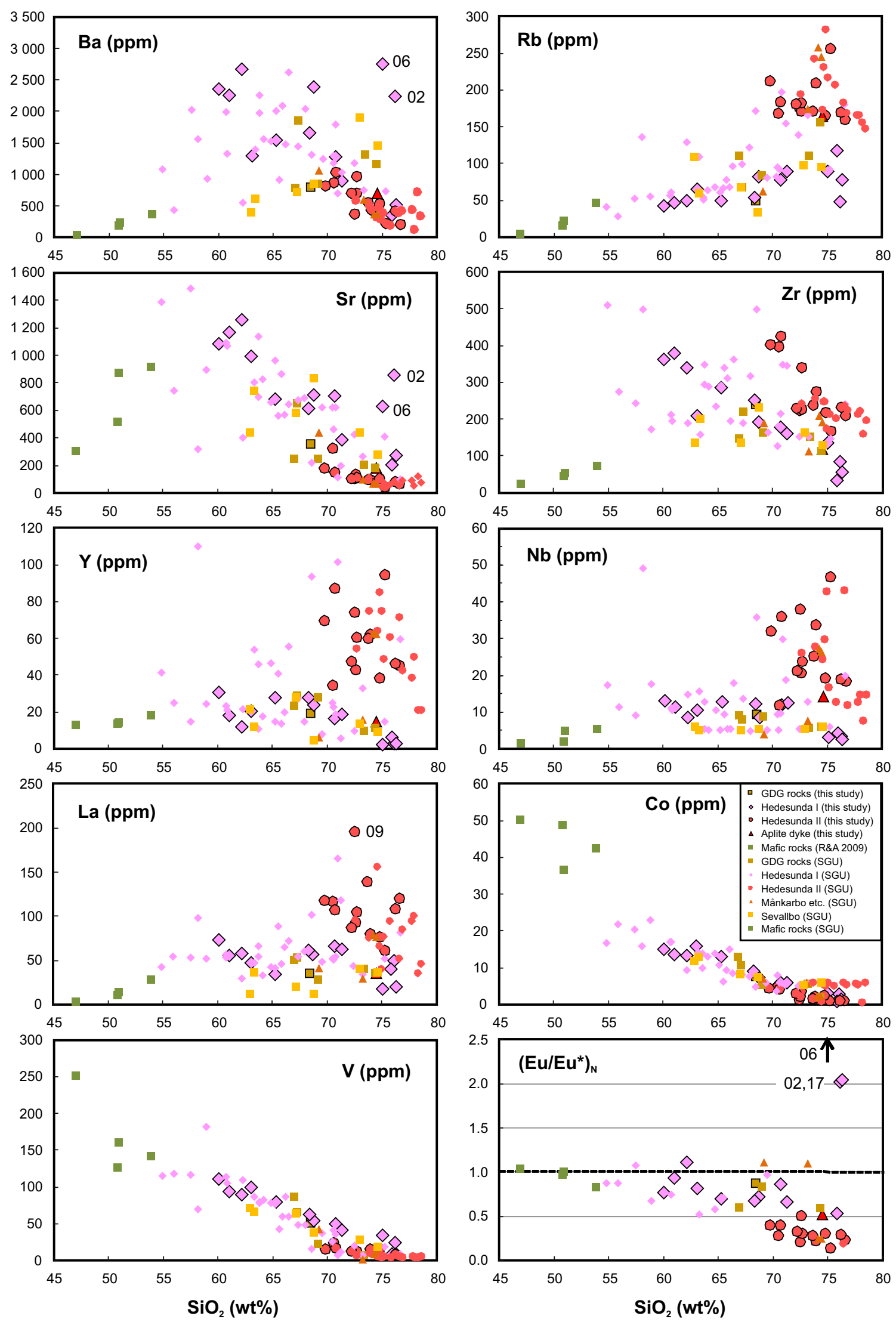
4Fig. 8 Selected trace elements versus $\mathrm{SiO}_{2}$ for all samples from the Hedesunda complex as well as immediately surrounding rock units [this study, SGU database samples, and mafic rock samples from Rutanen and Andersson (2009)]. Some outliers have been labelled with the last digits in their sample number

mafic samples $\left(\mathrm{SiO}_{2} 47-54 \mathrm{wt} \%\right)$, assumed to be related to the Hedesunda I granitoids, plot totally off the Hedesunda I differentiation trend, at least when it comes to $\mathrm{Al}_{2} \mathrm{O}_{3}, \mathrm{TiO}_{2}$, and $\mathrm{P}_{2} \mathrm{O}_{5}$, and thus appear not to be co-magmatic with the Hedesunda I granitoid suite.

For trace elements versus silica (Fig. 8), examples both of increasing and decreasing trends, as well as scatter, can be seen. In many cases, however, clear differences are seen between the Hedesunda I and II samples. For $\mathrm{Zr}$ and $\mathrm{Hf}$, and to some extent Ga (not shown), the Hedesunda II samples follow a parallel but higher trend (at any given $\mathrm{SiO}_{2}$ value) compared to the Hedesunda I samples, whereas the opposite is true for Sr and V. For many of the trace elements depicted, the Hedesunda II samples scatter without any well-defined trend, but fall at consistently higher trace element concentrations at the high-silica end of the spectrum than do the Hedesunda I samples. This is true for Rb, Th, U, Y, Nb, La, and $\mathrm{Yb}$ as well as for the $\mathrm{Rb} / \mathrm{Sr}$ ratio.

\section{Trace and rare earth element variation diagrams}

Trace and rare earth element variation diagrams for the different sets of samples are plotted in Fig. 9, with the trace element concentrations normalized to N-MORB (Sun and McDonough 1989) and the rare earth element concentrations normalized to chondrite values (Sun and McDonough 1989).

From the older GDG orthogneisses immediately surrounding the Hedesunda granite complex, only four samples (sample $\AA$ J17:07 and three of the SGU samples) with appropriate trace and rare earth element analysis were available (much more data are available in the SGU database if a wider geographic area would be considered). These four samples are plotted in Fig. 9a1 and a2. They show marked enrichment in LILE (Large Ion Lithophile Elements, i.e. K, $\mathrm{Rb}, \mathrm{Ba}$, and $\mathrm{Th}$ ), and negative spikes in $\mathrm{Nb}, \mathrm{P}$, and $\mathrm{Ti}$, as is typical for crustal, subduction-related rocks. In the REE diagram, they show moderate REE enrichment, with variably steep slopes $\left((\mathrm{La} / \mathrm{Yb})_{\mathrm{N}} 7.2-32\right)$ and small to moderate negative Eu anomalies $\left(\left(\mathrm{Eu} / \mathrm{Eu}^{*}\right)_{\mathrm{N}} 0.59-0.86\right)$.

The six SGU samples from the Sevallbo migmatite granite at the southern rim of the Hedesunda granite complex did not contain a full set of trace and rare earth element analysis and could thus not be plotted in the above diagrams. One sample from this intrusion, collected, analysed, and dated (to $1880 \pm 4 \mathrm{Ma}$ ) by Johansson and Stephens (2017), however, has similar trace and rare earth element patterns as the GDG gneisses as well as the Hedesunda I granitoids (Fig. 9a1 and a2).

From rocks classified as Hedesunda I granitoids, twentytwo samples (13 from this study and 9 SGU samples) with full trace element data were available and are plotted in Fig. $9 b 1$ and b2. The trace and rare earth element patterns for most of the samples are similar to the surrounding GDG orthogneisses, with marked enrichment in LILE, negative spikes for $\mathrm{Nb}, \mathrm{P}$, and $\mathrm{Ti}$, moderate enrichment in REE, $(\mathrm{La} / \mathrm{Yb})_{\mathrm{N}}$ varying between 6.8 and 50 (with two outliers at higher values; cf. Online Resource 2), and slightly positive to moderately negative Eu anomalies $\left(\left(\mathrm{Eu} / \mathrm{Eu}^{*}\right)_{\mathrm{N}} 0.52-1.11\right)$.

Four highly fractionated siliceous Hedesunda I samples $\left(\mathrm{SiO}_{2}=75.0-76.3 \mathrm{wt} \%\right)$, however, stand out with markedly lower REE concentrations. ÅJ17:07 and 17 are low both in LREE and HREE, whereas $\AA J 17: 02$ and 03 are low in HREE only. Three of these samples have anomalous positive Eu anomalies with $\left(\mathrm{Eu} / \mathrm{Eu}^{*}\right)_{\mathrm{N}}$ between 2.0 and 3.9 (cf. diagram in Fig. 8). These positive Eu anomalies are due to strong depletion in the other rare earth elements, normally contained in various accessory minerals, whereas the concentration of plagioclase-hosted Eu is in the same range as in the other samples.

The aplite sample ÅJ17:29 with $74.5 \mathrm{wt} \% \mathrm{SiO}_{2}$ has been plotted in the same diagrams and shows similar characteristics as the normal Hedesunda I samples. $\mathrm{K}, \mathrm{Rb}$, and Th are a bit higher, Ba shows a negative spike, and HFSE (High Field Strength Elements) are a bit less enriched, compared to most other Hedesunda I samples, with the negative $\mathrm{P}, \mathrm{Ti}$, and $\mathrm{Eu}$ anomalies being more marked $\left(\left(\mathrm{Eu} / \mathrm{Eu}^{*}\right)_{\mathrm{N}} 0.52\right)$.

Among the rocks classified as Hedesunda II granite, fourteen samples with full and reliable trace element data were available (13 from this study and only one of the SGU samples). These are plotted in Fig. 9c1 and c2. As for most granitoids, the patterns are generally similar, but some differences can be discerned compared to the Hedesunda I rocks. The Hedesunda II rocks are even more strongly enriched in $\mathrm{Rb}$ and $\mathrm{Th}$ but show a negative spike in $\mathrm{Ba}$, and the negative $\mathrm{P}$ and Ti anomalies are much more strongly marked. They also tend to be more strongly enriched in REE, but with more marked negative Eu anomalies $\left(\left(\mathrm{Eu} / \mathrm{Eu}^{*}\right)_{\mathrm{N}} 0.14-0.50\right)$ and generally less steep slopes $\left((\mathrm{La} / \mathrm{Yb})_{\mathrm{N}} 4.6-30\right)$.

In the SGU database, there were also four samples from similar young (not dated, but considered late-orogenic) granites to the east of the Hedesunda granite complex, three from the Månkarbo massif southeast of Tierp and one from the area east of Tierp also marked as late-orogenic GP granite on the SGU map, which are plotted for comparative purposes in Fig. 9d1 and d2. Two of the Månkarbo samples have identical trace and rare earth element patterns as the Hedesunda II granitoids, while the third Månkarbo sample and the sample east of Tierp have more or less deviating patterns. 
A more general comparison of the surrounding granitoid massifs with the Hedesunda I and II granitoids using all available diagrams shows that the GDG orthogneisses and the Sevallbo migmatite granite in most respects are geochemically similar to the Hedesunda I granitoids and form similar trends in most plots. The late-orogenic Månkarbo granite seems to be more similar to the Hedesunda II granite, as may be expected, and as far as can be deduced from the limited data.

\section{Sr and Nd isotope geochemistry}

Eight of the Hedesunda I and ten of the Hedesunda II wholerock samples were analysed for their $\mathrm{Sr}$ and $\mathrm{Nd}$ isotope composition, with the results reported in Tables 3 and 4 and illustrated in Fig. 10a and b, respectively.

Given the difference in $\mathrm{Rb} / \mathrm{Sr}$ ratios between the Hedesunda I and II granitoids noted above, the Hedesunda I samples have substantially lower ${ }^{87} \mathrm{Rb} /{ }^{86} \mathrm{Sr}$ ratios, with one exception below 1 . Their initial ${ }^{87} \mathrm{Sr} /{ }^{86} \mathrm{Sr}$ ratios, calculated at $1865 \mathrm{Ma}$, fall between 0.7023 and 0.7037 except for in one sample, corresponding to $\varepsilon_{\mathrm{Sr}}(i)$ between 0 and +19 , at or slightly above the mantle evolution line (UR in Fig. 10a). The mafic Hedesunda I rock analysed by Rutanen and Andersson (2009) shows a similar initial isotope composition. The somewhat more $\mathrm{Rb}$-rich and $\mathrm{Sr}$-poor sample ÅJ17:03 with ${ }^{87} \mathrm{Rb} /{ }^{86} \mathrm{Sr}$ of 1.644 is somewhat disturbed in its $\mathrm{Rb}-\mathrm{Sr}$ systematics and yields an anomalously low initial ${ }^{87} \mathrm{Sr} /{ }^{86} \mathrm{Sr}$ ratio of 0.6995 , corresponding to $\varepsilon_{\mathrm{Sr}}(i)$ of -40 .

The Hedesunda II samples all have ${ }^{87} \mathrm{Rb} /{ }^{86} \mathrm{Sr}$ ratios above 3, with one extreme sample ( $\mathrm{J} J 17: 18$ ) being as high as 16.6. As is often the case with $\mathrm{Rb}$-rich rocks, their $\mathrm{Rb}-\mathrm{Sr}$ systematics have been disturbed so that their initial $\mathrm{Sr}$ isotope values (calculated at $1785 \mathrm{Ma}$ ) scatter widely on both sides of the mantle evolution line, from ${ }^{87} \mathrm{Sr} /{ }^{86} \mathrm{Sr} 0.6783\left(\varepsilon_{\mathrm{Sr}}(i)\right.$ $-343)$ to ${ }^{87} \mathrm{Sr} /{ }^{86} \mathrm{Sr} 0.7079\left(\varepsilon_{\mathrm{Sr}}(i)+78\right.$; Fig. 10a).

Normally, more felsic rocks with high $\mathrm{Rb} / \mathrm{Sr}$ ratios, as the Hedesunda II granitoids, would be expected to have low $\mathrm{Sm} / \mathrm{Nd}$ ratios. However, in the case of the Hedesunda rocks, the Hedesunda II samples instead mostly have higher $\mathrm{Sm} /$ $\mathrm{Nd}$ ratios than the Hedesunda I samples, with a dividing line around ${ }^{147} \mathrm{Sm} /{ }^{144} \mathrm{Nd}$ of 0.100 .

The Hedesunda I samples thus have ${ }^{147} \mathrm{Sm} /{ }^{144} \mathrm{Nd}$ ratios between 0.0587 and 0.1005 . Initial $\varepsilon_{\mathrm{Nd}}$ (at $1865 \mathrm{Ma}$ ) fall in a very narrow range between 0 and +1 (with $\AA \mathrm{J} 17: 03$ also here standing out as the lowest value), suggesting a juvenile origin with no variation between intermediate and felsic members of the Hedesunda I suite (Fig. 10b). The mafic Hedesunda I sample analysed by Rutanen and Andersson (2009) plots at a slightly more depleted initial value of +1.4 . In terms of $\mathrm{Nd}$ model ages, the Hedesunda I granitoid samples have $T_{\mathrm{CHUR}}$ of 1.79 to $1.85 \mathrm{Ga}$, and $T_{\mathrm{DM}}$ (De Paolo 1981) of 2.04-2.11 Ga.

The Hedesunda II samples have systematically higher ${ }^{147} \mathrm{Sm} /{ }^{144} \mathrm{Nd}$ ratios between 0.1005 and 0.1483 . Initial $\varepsilon_{\mathrm{Nd}}$ (at $1785 \mathrm{Ma}$ ) fall between +0.4 and +1.8 , overlapping or slightly higher than the Hedesunda I samples (Fig. 10b). However, at $1785 \mathrm{Ma}$, the Hedesunda I samples would have evolved to $\varepsilon_{\mathrm{Nd}}$ values between 0 and -1 . The Sm-Nd systematics thus show that the Hedesunda II granitoids did not originate from remelting of surrounding Hedesunda I rocks, or similar rocks at depth, but their magmas must have contained an additional, more juvenile component. In terms of Nd model ages, the Hedesunda II samples have $T_{\text {CHUR }}$ from 1.63 to $1.74 \mathrm{Ga}$, and $T_{\mathrm{DM}}$ (De Paolo 1981) of 1.95-2.06 Ga, with one sample ( $\mathrm{J} J 17: 18)$ at $2.17 \mathrm{Ga}$.

If initial $\varepsilon_{\mathrm{Nd}}$ is plotted against initial $\varepsilon_{\mathrm{Sr}}$ (not shown) for the apparently undisturbed samples (seven of the eight Hedesunda I samples, but only one Hedesunda II sample, ÅJ17:22), the data points fall in the upper right quadrant of the diagram, at $\varepsilon_{\mathrm{Nd}}$ between 0 and +2 and $\varepsilon_{\mathrm{Sr}}$ between 0 and +20 , similar to mafic Svecofennian rocks in the same region in east-central Sweden (Johansson et al. 2012; Johansson and Hålenius 2013; Dahlin et al. 2014; Johansson and Karlsson 2020).

\section{Hf isotope systematics}

In order to get further information on the petrogenesis and magma origin of the Hedesunda I and II granitoids, the $\mathrm{Lu}-\mathrm{Hf}$ isotope composition was analysed by LA-ICP-MS in almost all zircon crystals previously dated by $\mathrm{U}-\mathrm{Pb}$ in samples MBS000131A, HLD020767A, and LP94:1. Analytical data are listed in Online Resource 3, analytical spots with obtained initial $\varepsilon_{\mathrm{Hf}}$ values have been marked on the BSE and CL images of the zircons in Online Resources 6-11, and the data are summarized in Fig. 10c. Areas with magmatic-looking zircon was selected for the Hf isotope analysis, avoiding the inherited and highly metamict cores in sample LP94:1.

Since some of the Hf isotope analyses nevertheless are from zircons in samples MBS000131A and LP94:1 that have yielded discordant and younger ages than the accepted crystallization age, the question arises whether to use the average crystallization age for each sample, or the ${ }^{207} \mathrm{~Pb} /{ }^{206} \mathrm{~Pb}$ age obtained for each individual zircon which is sometimes younger, when calculating its initial $\varepsilon_{\mathrm{Hf}}$ value. Given that the areas with younger ${ }^{207} \mathrm{~Pb} /{ }^{206} \mathrm{~Pb}$ ages appear to consist of magmatic zircon, based on their texture and high $\mathrm{Th} / \mathrm{U}$ ratios, that has been disturbed in its U-Pb systematics, and not newly crystallized metamorphic overgrowths with low $\mathrm{Th} / \mathrm{U}$, it was considered appropriate to use the average crystallization age for each rock for all $\mathrm{Hf}$ analysis, also those from disturbed zircons, assuming that the more robust 


\section{A1}

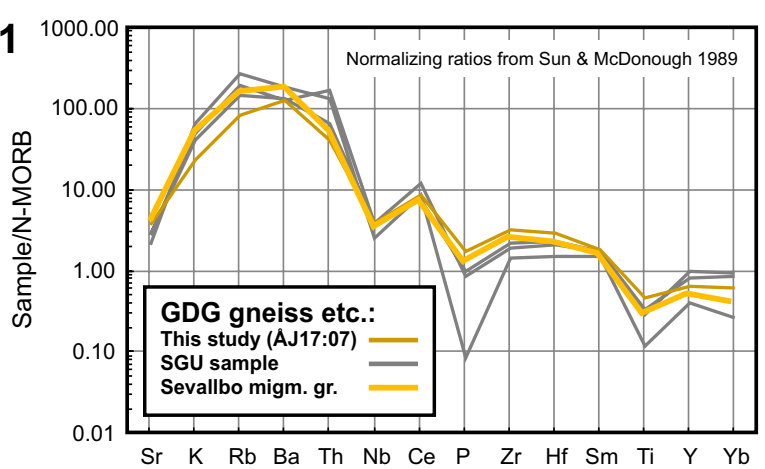

B1
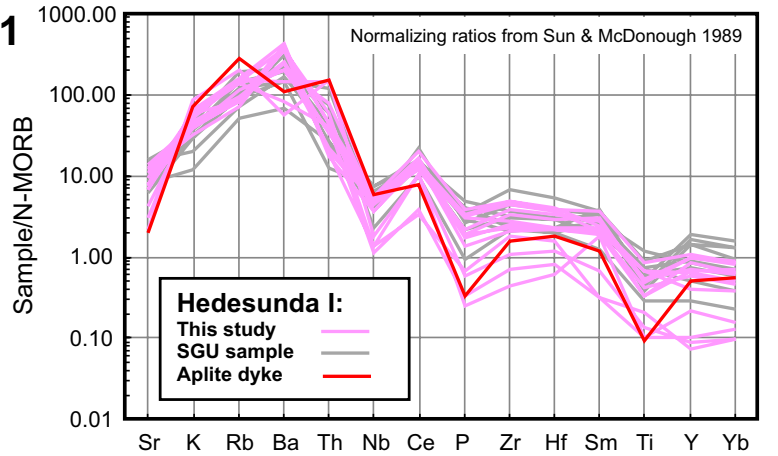

C1

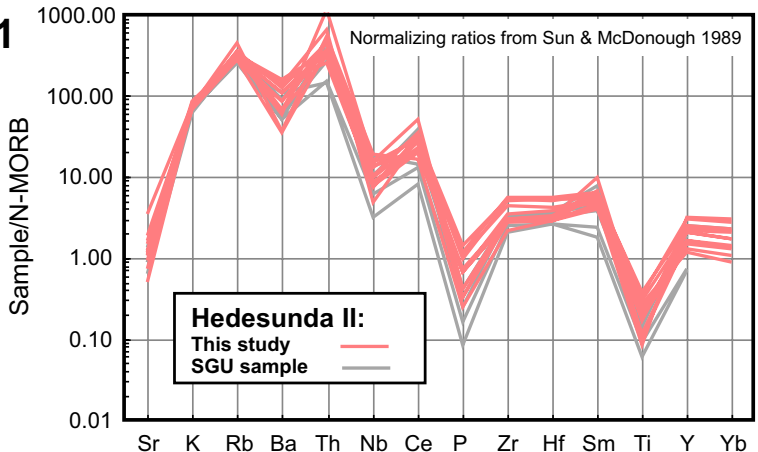

D1

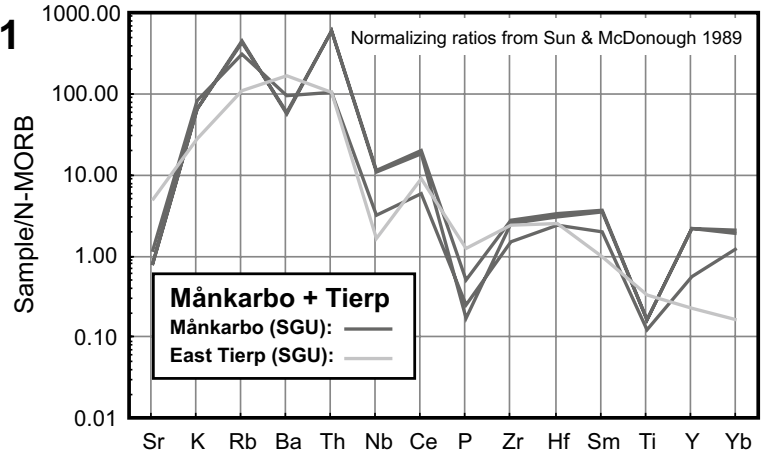

Fig. 9 Trace element variation (left column) and rare earth element variation (right column) diagrams for the Hedesunda complex and immediately surrounding rock units. Normalizing N-MORB and chondrite values from Sun and McDonough (1989). a GDG orthogneiss and Sevallbo migmatite granite. b Hedesunda I granitoids, plus

Lu-Hf system remained intact during the later disturbance, so that the measured ${ }^{176} \mathrm{Lu} /{ }^{177} \mathrm{Hf}$ ratio can be extrapolated back to the time of original zircon crystallization.
A2

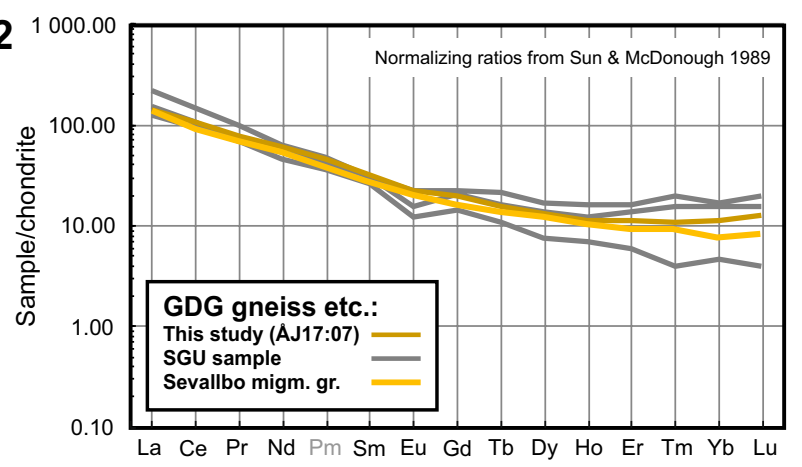

B2

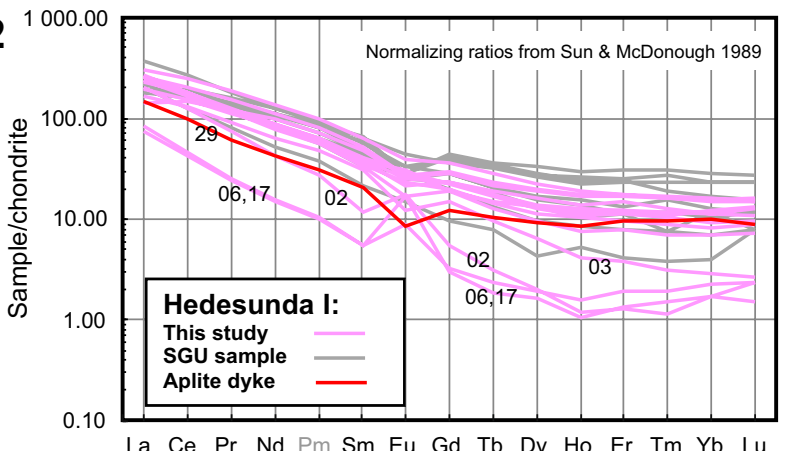

C2

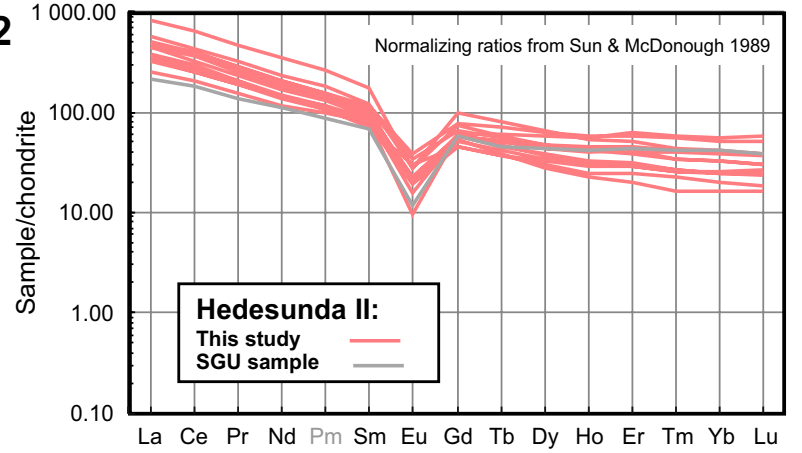

D2

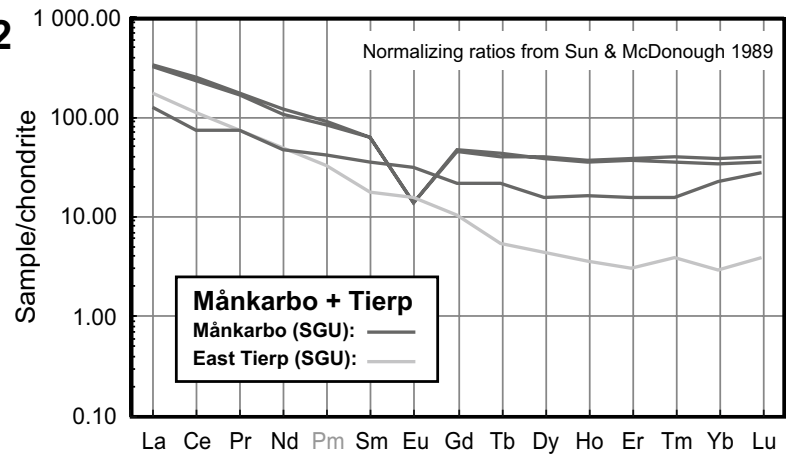

one aplite dyke sample. Low REE (and HFSE) samples are marked with the last digits in their sample number in the REE diagram. $\mathbf{c}$ Hedesunda II granite. d Late Svecofennian granite at Månkarbo and east of Tierp (SGU samples only)

Following that logic, the zircons from the two Hedesunda I samples $(n=13+15)$ have moderately depleted initial $\varepsilon_{\mathrm{Hf}}$ values between +1.1 and +4.4 at $1865 \mathrm{Ma}$ (Fig. 10c). Assuming an average crustal ${ }^{176} \mathrm{Lu} /{ }^{177} \mathrm{Hf}$ ratio of 0.0015 (cf. 


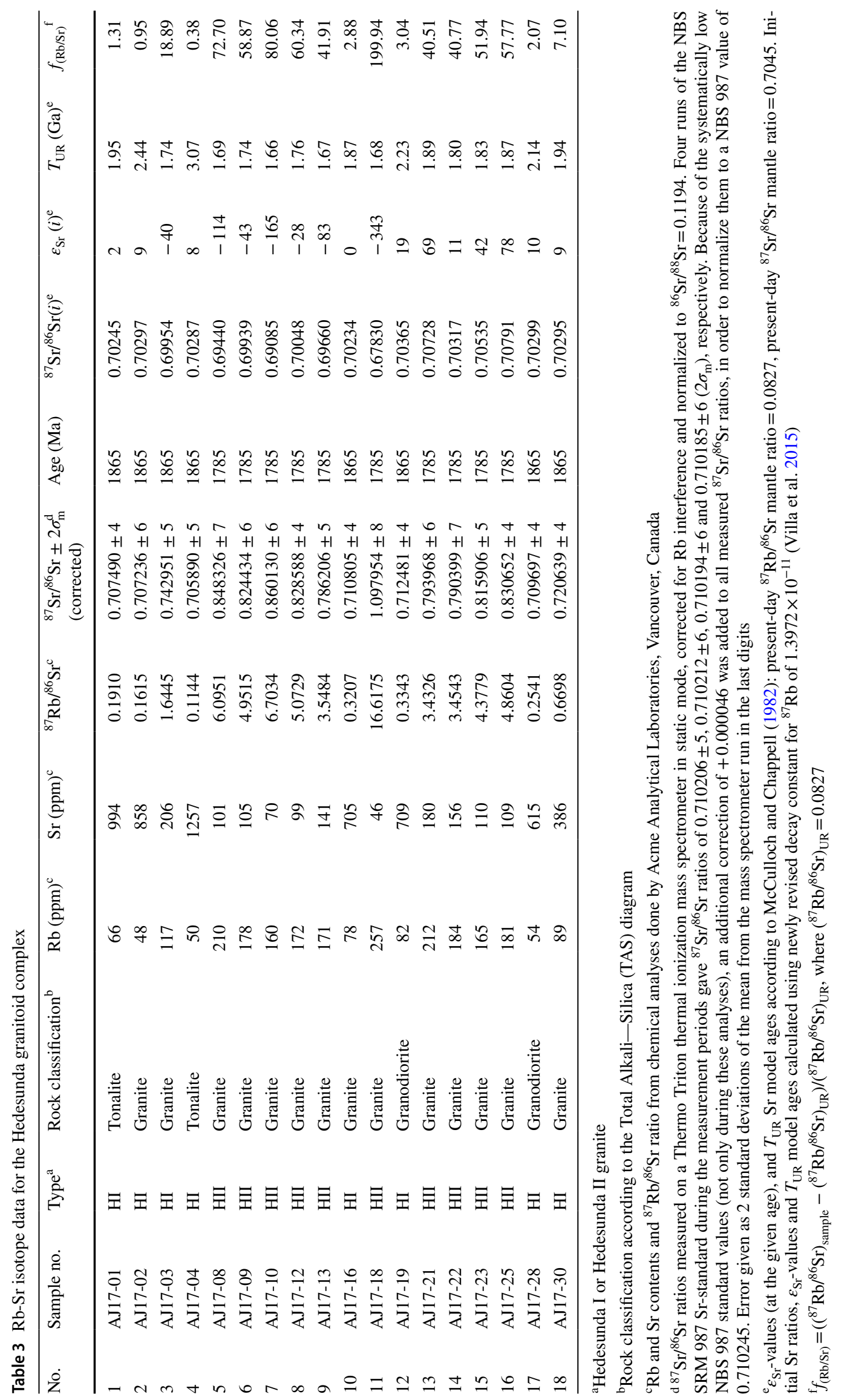




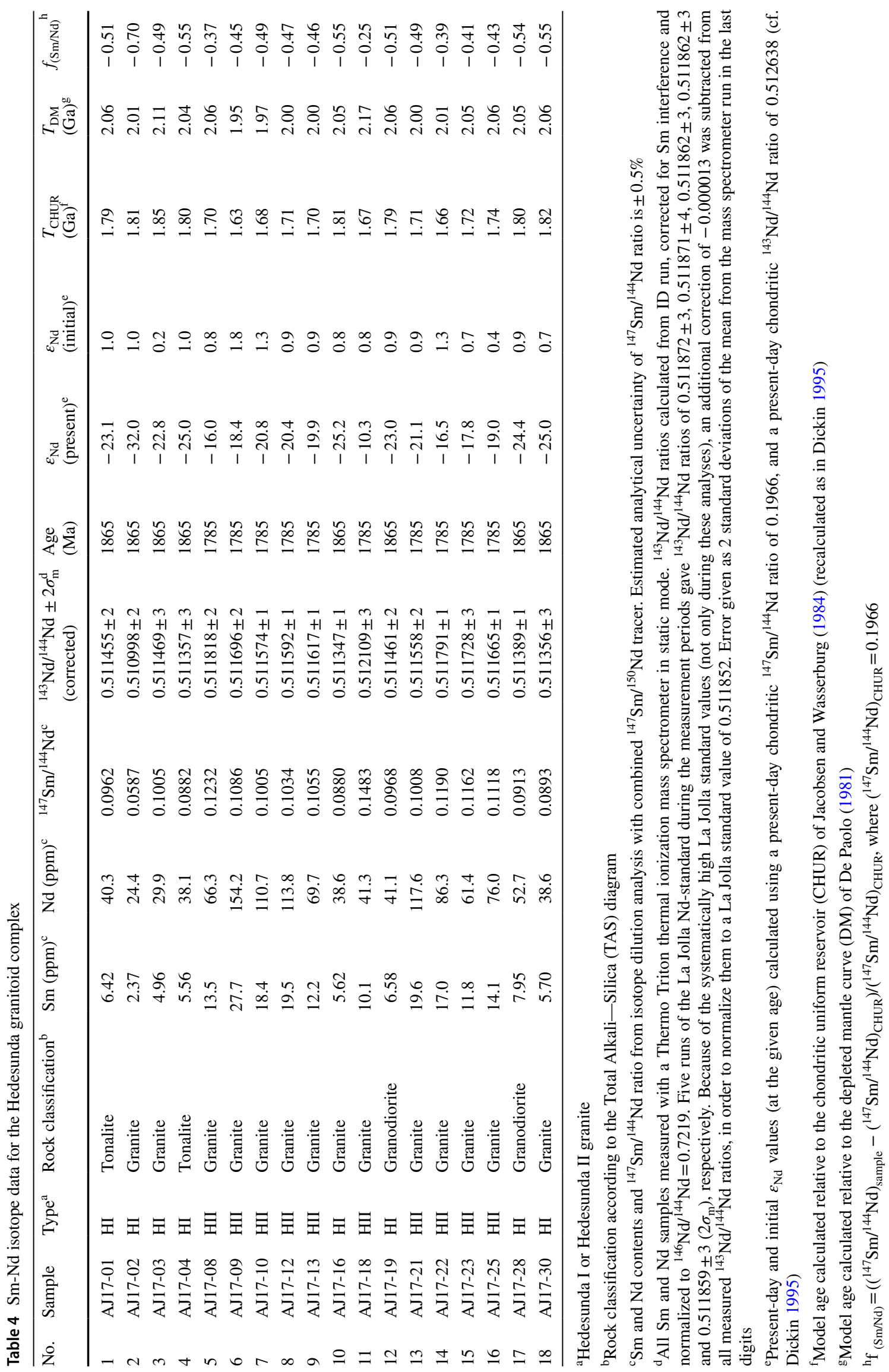


Spencer et al. 2020) in the protolith material of the Hedesunda I magma, this would correspond to $T_{\mathrm{DM} 2}$ model ages in the 2.2-2.4 Ga range, a bit higher than the $\mathrm{Nd} T_{\mathrm{DM}}$ model ages calculated above.

The zircons analysed from Hedesunda II sample LP94:1 $(n=15)$ have similar to slightly more positive initial $\varepsilon_{\mathrm{Hf}}$ values at $1785 \mathrm{Ma}$ of +2.5 to +4.8 (Fig. 10c). Using a similar protolith ${ }^{176} \mathrm{Lu} /{ }^{177} \mathrm{Hf}$ ratio of 0.0015 , this would correspond to $T_{\mathrm{DM} 2}$ model ages of 2.1 to $2.3 \mathrm{Ga}$, again a bit higher than the Nd $T_{\mathrm{DM}}$ model ages for the Hedesunda II granite calculated above.

Using the $\mathrm{Lu}$ and $\mathrm{Hf}$ concentrations in the new wholerock samples of both types, average ${ }^{176} \mathrm{Lu} /{ }^{177} \mathrm{Hf}$ ratios and $\mathrm{Hf}$ isotope evolution lines that the Hedesunda I and II samples would have followed after their crystallization can be calculated. The Hedesunda I granitoids then yield a rather low ${ }^{176} \mathrm{Lu} /{ }^{177} \mathrm{Hf}$ ratio of $0.0064 \pm 0.0027$, whereas the Hedesunda II granitoids yield a more normal crustal ${ }^{176} \mathrm{Lu} /{ }^{177} \mathrm{Hf}$ ratio of $0.0152 \pm 0.0067$, albeit with considerable scatter around the average value. If whole-rock Hf evolution trends based on these averages are drawn for the Hedesunda I and II granitoids in Fig. 10C, it can be seen that the Hedesunda II magma cannot have formed by pure remelting of Hedesunda I rocks but must contain some more juvenile depleted component, similar to what was deduced based on the $\mathrm{Nd}$ isotope data above.

\section{Discussion}

\section{Distribution of Hedesunda I and II rocks within the Hedesunda complex}

The assignment of samples to the Hedesunda I or II intrusions was based on their location relative to the recent SGU bedrock map (Fig. 1), and their character as observed in the field or deduced from the SGU database. A relatively straightforward and clear geochemical division was then found to exist between the two sample groups, as outlined above. The geochemical subdivision largely confirms the subdivision made between the two granitoid types on the SGU maps (Delin and Söderman 2005a, b; Bergman and Söderman 2005a, b), based on field mapping and aeromagnetics, with a circular Hedesunda II massif in the northcentral part and an elongated Hedesunda II massif in the northwestern part, as shown in Fig. 1.

However, a few samples within the Hedesunda I areas have Hedesunda II petrographic and geochemical characteristics, necessitating slight revisions of the map pattern (cf. Fig. 1). This is true for the northwest corner of the Hedesunda I massif close to highway 56, and along the Dalälven river northwest of Söderfors in the central area. However, it is beyond the scope of this paper to do any actual revision of the geological map.

\section{Tectonic setting and petrogenesis}

In Fig. 11, some additional geochemical diagrams are shown, in order to illustrate the differences between the Hedesunda I and II granitoids, as well as adjacent rock units (GDG orthogneisses, Sevallbo migmatite granite, Månkarbo granite, and mafic rocks included within and presumed to be related to the Hedesunda I intrusion).

In Fig. 11a-e, selected major and trace elements have been plotted relative to the immobile trace element $\mathrm{Zr}$, illustrating the different fractionation trends displayed by the two generations of Hedesunda granites. From these diagrams, it is also clear that the above-mentioned mafic rocks do not fall on the same differentiation trend as any of the Hedesunda granitoids. Although they may still be co-genetic with the Hedesunda I granitoids, they do not appear to be comagmatic but must have originated from a separate magma.

In Fig. 11f $-\mathrm{h}$, the separation between Hedesunda I and II samples when it comes to their concentrations of various large ion lithophile elements, such as $\mathrm{Rb}, \mathrm{Sr}, \mathrm{Ba}$, and $\mathrm{Th}$, is clearly visible.

In Fig. 11i, j, a compatible element ( $\mathrm{V}$ and $\mathrm{Sr}$, respectively) has been plotted versus an incompatible ( $\mathrm{Rb})$, on a logarithmic scale. In such diagrams, rock suites that have formed by fractional crystallization will dominantly follow steep trends, and rock suites whose variation is mainly due to different degrees of partial melting of their sources will follow flat trends (Cocherie 1986). These diagrams again indicate the differences between the Hedesunda I and II granitoids, and between the former and the related mafic rocks. The mafic rocks display flat trends, suggesting that they formed by different degrees of partial melting of a mantle source, whereas the two granitoid suites display separate steep trends, suggesting fractional crystallization of magmas that may have originated in the lower crust.

In Fig. 12, the investigated rocks have been plotted in various discrimination diagrams. In the diagram of Whalen et al. (1987), the Hedesunda I samples dominantly plot as unfractionated to fractionated I-, S- or M-type granites, although straddling into the A-type field (Fig. 12a). The Hedesunda II samples plot as A-type granite. In the Rb vs. $\mathrm{Y}+\mathrm{Nb}$ diagram of Pearce et al. (1984), the Hedesunda I samples dominantly plot as volcanic-arc granites, and the Hedesunda II samples as within-plate granites (Fig. 12b). However, the latter samples also fall within the overlapping circular field of post-collisional granites added by Pearce (1996).

Väisänen et al. (2012b) showed that some magmatism in southern Finland towards the end of the synorogenic accretionary stage of the Svecofennian orogeny at ca $1.87 \mathrm{Ga}$ had 
Fig. 10 a Initial $\varepsilon_{\mathrm{Sr}}$ versus age for the Hedesunda I (H-I) and Hedesunda II (H-II) granitoids, plus one mafic rock sample related to the Hedesunda I intrusion analysed by Rutanen and Andersson (2009). The Hedesunda II samples show considerable scatter due to disturbances of their $\mathrm{Rb}-\mathrm{Sr}$ systems. UR Uniform (mantle) reservoir. b Initial $\varepsilon_{\mathrm{Nd}}$ versus age for the Hedesunda I (H-I) and Hedesunda II (H-II) granitoids, plus one mafic rock sample related to the Hedesunda I intrusion analysed by Rutanen and Andersson (2009). CHUR Chondritic uniform reservoir, $D M$ Depleted mantle according to De Paolo (1981). c Initial $\varepsilon_{\mathrm{Hf}}$ for Hedesunda I (H-I) and Hedesunda II (H-II) zircons.

CHUR chondritic uniform reservoir, $D M$ depleted mantle according to Griffin et al. (2000). For the time prior to crystallization and back to the DM curve, evolution lines for the magma sources assuming an average crustal ${ }^{176} \mathrm{Lu} /{ }^{177} \mathrm{Hf}$ ratio of 0.015 (Spencer et al. 2020) are drawn. For the time after crystallization, average evolution lines for the Hedesunda I and II granitoids with ${ }^{176} \mathrm{Lu} /{ }^{177} \mathrm{Hf}$ of 0.006 and 0.015 , respectively, based on the average whole-rock $\mathrm{Lu} / \mathrm{Hf}$ values for each rock unit, are drawn
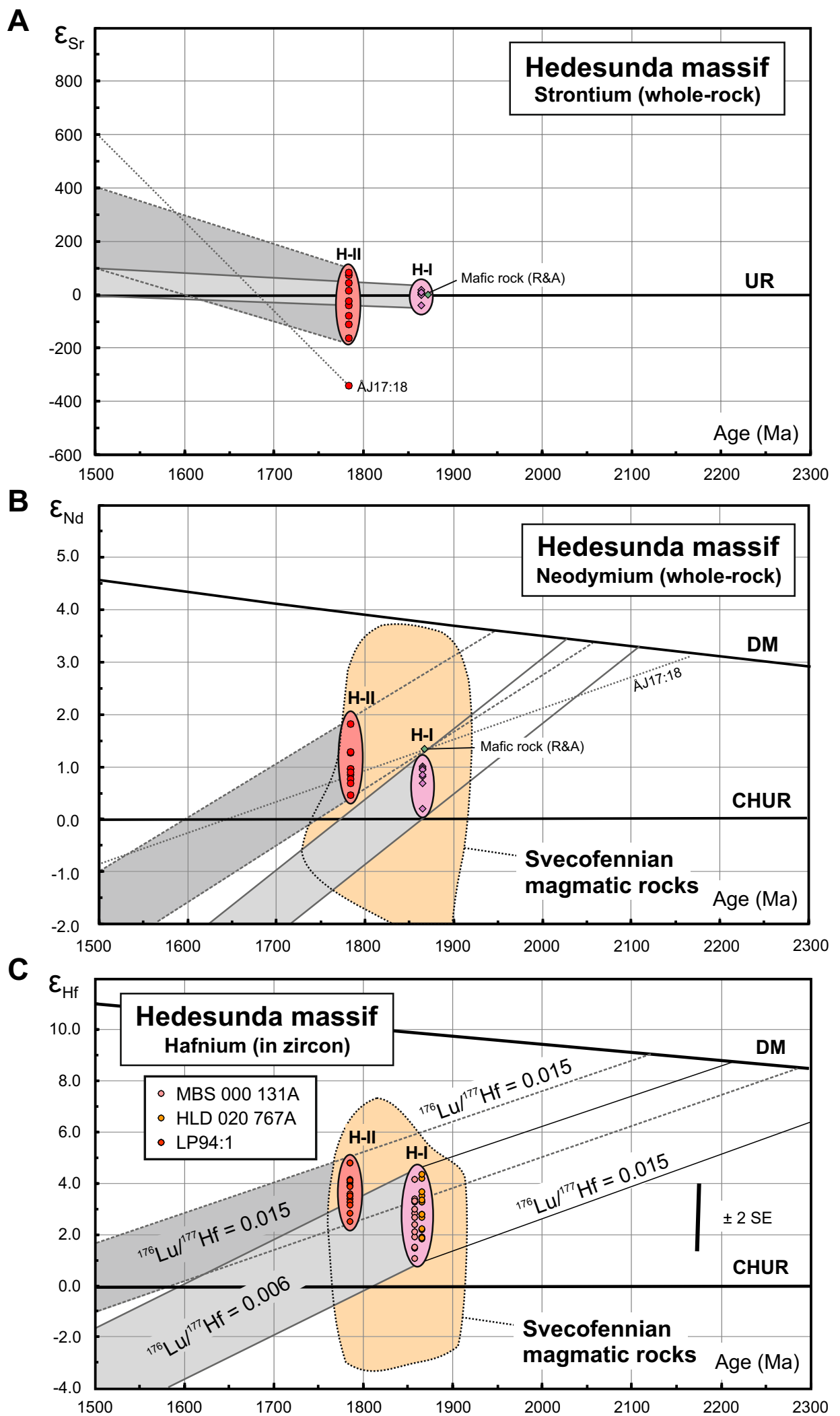

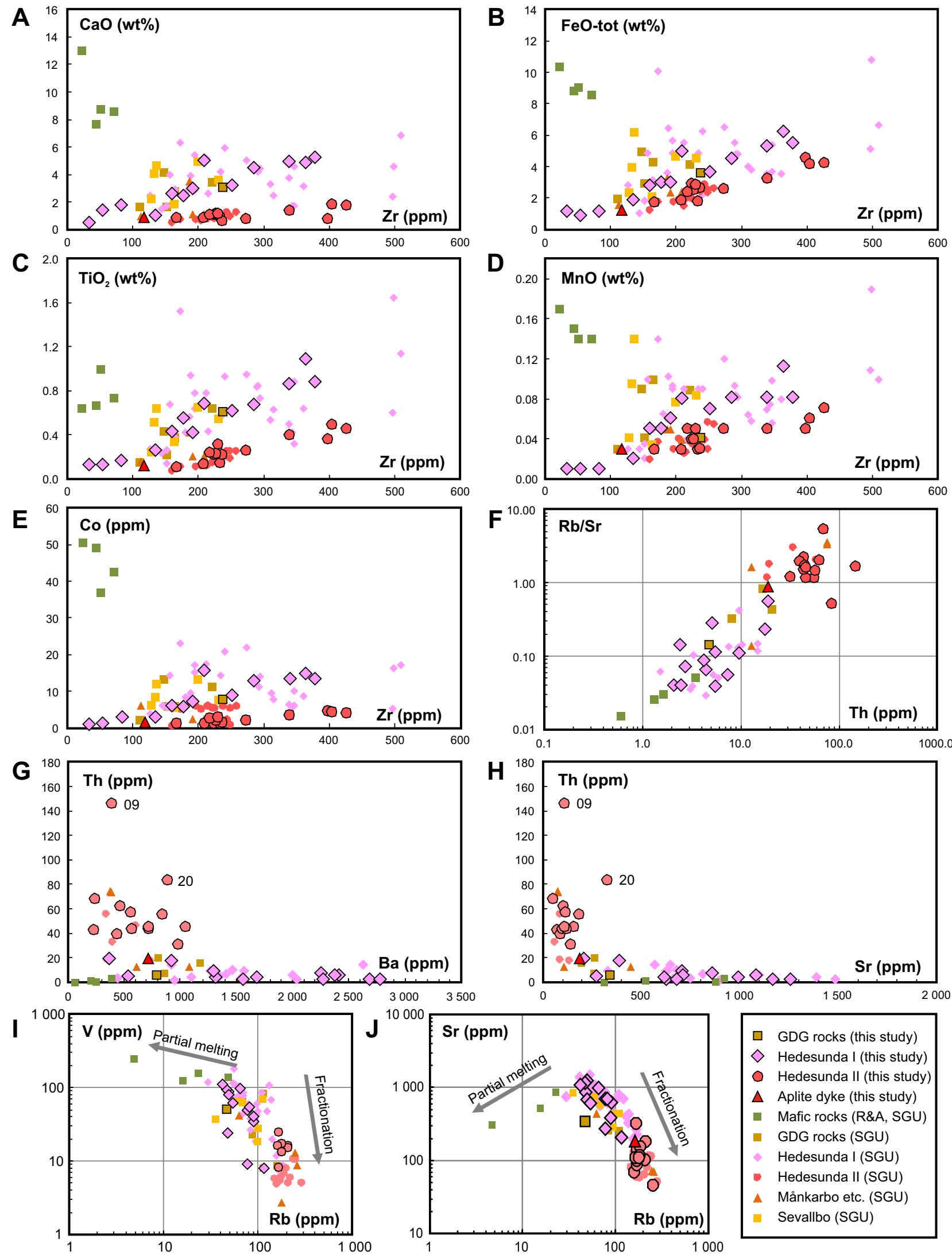

$\square$ GDG rocks (this study)

$\diamond$ Hedesunda I (this study)

- Hedesunda II (this study)

$\triangle$ Aplite dyke (this study)

- Mafic rocks (R\&A, SGU)

- GDG rocks (SGU)

- Hedesunda I (SGU)

- Hedesunda II (SGU)

$\Delta \quad$ Månkarbo etc. (SGU)

- Sevallbo (SGU) 
४Fig. 11 a-e Selected major and trace elements versus $\mathrm{Zr}$, illustrating the different fractionation trends for the Hedesunda I and II granitoids, as well as the deviation of the mafic Hedesunda I samples from the Hedesunda I granitoid trend, suggesting different magma sources. f-h $\mathrm{Rb} / \mathrm{Sr}$ vs. Th, Th vs. $\mathrm{Ba}$, and $\mathrm{Th}$ vs. $\mathrm{Sr}$ diagrams, illustrating the separation in large ion lithophile element concentrations and ratios between the Hedesunda I and II granitoids. i, j Logarithmic V vs. Rb and $\mathrm{Sr}$ vs. Rb diagrams, showing the different trends for the mafic Hedesunda I samples (flat trends caused by different degrees of partial melting in the source), and the intermediate to felsic Hedesunda I and II granitoids (steep trends caused by fractionation; cf. Cocherie 1986; De Souza et al. 2007)

an adakitic character (Defant and Drummond 1990). In the $\mathrm{Sr} / \mathrm{Y}$ vs. Y diagram, the Hedesunda I samples mainly plot as typical arc rocks, but with a somewhat adakitic tendency (Fig. 12c). However, the two samples plotting highest up in the adakitic field with highly elevated $\mathrm{Sr} / \mathrm{Y}$ ratios $(\AA \mathrm{J} 17: 02$ and 06) have anomalous $\mathrm{Sr}$ concentrations, possibly due to some cumulate plagioclase, plotting above the $\mathrm{Sr}$ vs. $\mathrm{SiO}_{2}$ trend shown in Fig. 8. Disregarding those two outliers, the Hedesunda I granitoid cannot really be considered adakitic.

In the ternary Hf-Rb-Ta diagram of Harris et al. (1986), the Hedesunda I samples fall in the volcanic arc granite field (Fig. 12d). The Hedesunda II samples fall in an area where volcanic arc and collision-related granites overlap.

In summary, the Hedesunda I granitoids may be considered I-type, calc-alkaline, magnesian granites formed in a continental arc setting, shortly after the main stage of Svecofennian accretionary magmatism and deformation, possibly during an extensional episode with magmatic underplating triggering melting of the newly formed Svecofennian crust. The Hedesunda II intrusions are A-type high-K calc-alkaline to shoshonitic ferroan granites, formed 80 million years later in a late- to post-orogenic setting.

\section{The Hedesunda I and II granitoids seen in a wider regional context}

The new U-Pb SIMS data confirm the earlier U-Pb TIMS ages, indicating that the Hedesunda granitoid massif is a composite intrusion, composed of an early Hedesunda I phase with an age around $1865 \mathrm{Ma}$, and a much younger Hedesunda II phase with an age at ca. $1785 \mathrm{Ma}$.

In Fig. 13, the newly obtained Hedesunda I and Hedesunda II ages have been inserted in a diagram of all magmatic U-Pb zircon ages (with an uncertainty less than \pm 20 million years) within the whole Bergslagen lithotectonic unit, obtained from the age database of the Geological Survey of Sweden (SGU). The underlying data are shown in Online Resource 4. This may be seen as an update of the diagrams published by Stephens et al. (2009) and follows the same division of rock types: felsic volcanic rocks, GDG (granite-diorite-gabbro) intrusives, GSDG intrusives, and GP (granite-pegmatite) intrusives. In addition, shaded bands outlining the ranges of metamorphic ages within the Bergslagen lithotectonic unit, as summarized in Johansson and Stephens (2017), have been added.

In this diagram, the narrow range in ages for felsic metavolcanic rocks in Bergslagen between 1.91 and $1.88 \mathrm{Ga}$ is seen, as well as the overlapping age range for the GDG intrusives, which however extends all the way down to $1.85 \mathrm{Ga}$. Intrusives assigned to the GSDG group by Stephens et al. (2009) largely overlaps with the younger GDG intrusives at $1.88-1.84 \mathrm{Ga}$, including intrusions along the southwest margin of the Bergslagen lithotectonic unit (TIB-0), but disregarding much younger intrusives further west (TIB-1). The new Hedesunda I ages have been placed within the GSDG group, following Stephens et al. (2009), but according to the geochemical data presented above they should rather be moved left into the tail of the GDG group, as indicated by the horizontal arrows in the diagram. These emplacement ages overlap with the first group of metamorphic ages from Bergslagen (Metamorphism 1), although most of the regional deformation in the Hedesunda area clearly occurred prior to the intrusion of the Hedesunda I granitoids at around $1865 \mathrm{Ma}$.

The GP intrusive rocks cover a very wide age range from 1.85 to $1.75 \mathrm{Ga}$, possibly with some gaps, and largely overlap with the second metamorphic episode in Bergslagen. However, most of the published ages for GP rocks are TIMS ages and should thus be taken with some caution, since they may be affected by inheritance or later disturbances. The Hedesunda II age at around $1785 \mathrm{Ma}$ fall in the middle of this age group. However, just as with the Hedesunda I granitoids, the assignment of the Hedesunda II granite within the GP group may be disputed. Although it has a purely granitic composition, its geochemical characteristics are not those of a typical low-temperature crustal anatectic granite, but rather akin to high-temperature A-type granites.

The Ljusdal lithotectonic unit occurs immediately north of the Bergslagen lithotectonic unit (see inset map in Fig. 1), separated by a system of crustal-scale shear zones that were initiated at $1.87-1.86 \mathrm{Ga}$ and remained active to at least $1.81 \mathrm{Ga}$ (Högdahl et al. 2009), during oblique Sarmatia-Fennoscandia convergence and collision from the southeast (e.g. Lahtinen et al. 2005, Bogdanova et al. 2015). The Ljusdal unit is dominated by pervasively deformed synorogenic GDG intrusive rocks (Ljusdal batholith) with ages of 1.87-1.86 Ga (Högdahl et al. 2008, SGU geochronological database), younger than the dominant synorogenic magmatism within the Bergslagen unit (1.91-1.87 Ga Bergslagen GDG suite, Stephens et al. 2009), but contemporaneous with the intrusion of the Hedesunda I granitoids within the northern part of the Bergslagen lithotectonic unit, only some 20-30 km south of the tectonic boundary between the two units. However, the distance between the two lithotectonic units may have been much larger at that time, prior to the 

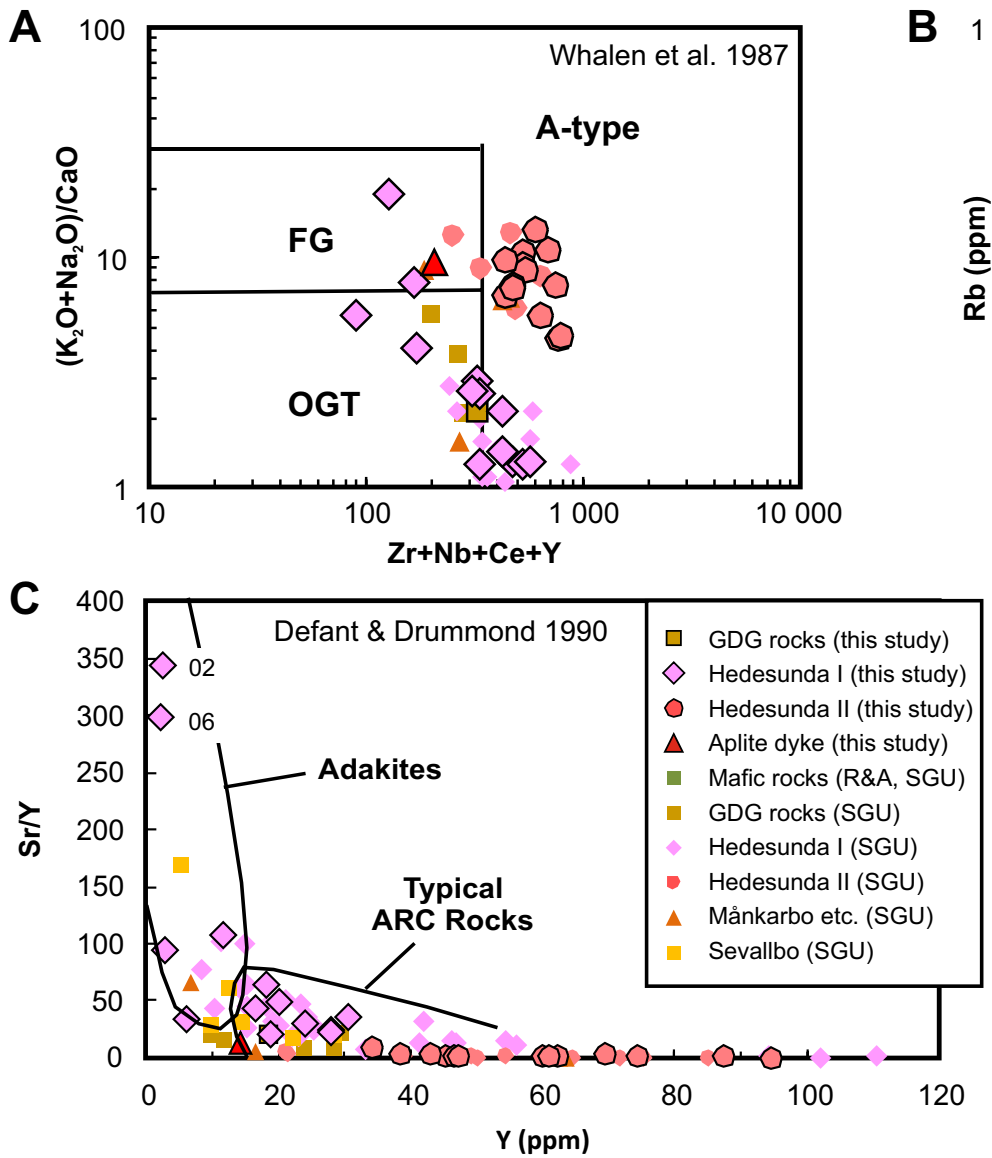

B
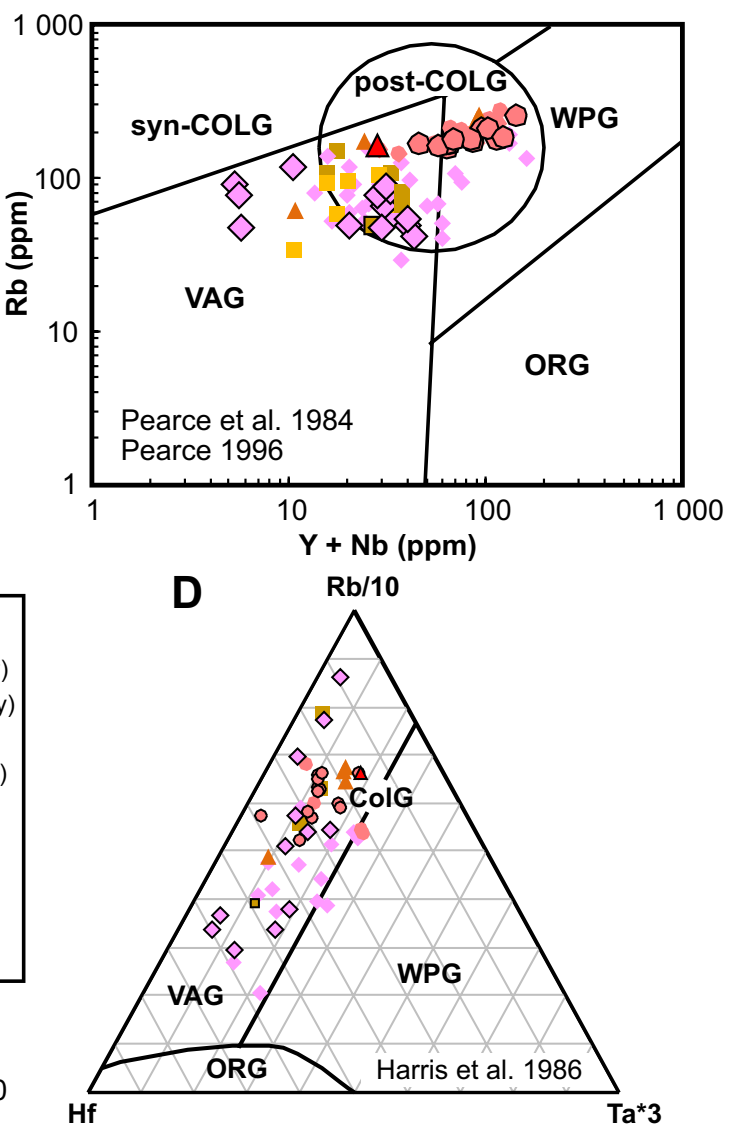

Fig. 12 Tectonic discrimination diagrams. a Diagram by Whalen et al. (1987), showing the I-type character of the Hedesunda I granitoids, and the A-type character of the Hedesunda II granitoids. $O G T$ unfractionated I-, S- and M-type granites, $F G$ fractionated granites. b Tectonic discrimination diagram for granites by Pearce et al. (1984). $O R G$ ocean ridge granites, VAG volcanic arc granites, syn-COLG syn-collisional granites, $W P G$ within-plate granites, post-COLG (Pearce 1996) post-collisional granites. c Sr/Y vs. Y diagram from Defant and Drummond (1990), separating adakites from typical arc rocks. d Ternary Hf- $\mathrm{Rb}-\mathrm{Ta}$ discrimination diagram by Harris et al. (1986). ORG ocean ridge granites, VAG volcanic arc granites, WPG within-plate granites, $\mathrm{Col} G$ collision granites late Svecofennian oblique convergence and collision with Sarmatia, which displaced the crustal blocks in the southern part of the Svecofennian orogen in a northwestward direction. At 1.87-1.86 Ga, the Ljusdal and Bergslagen lithotectonic units were apparently under different tectonic regimes, with the Ljusdal unit still undergoing synorogenic magmatism and deformation, while the Bergslagen unit had entered an extensional intra-orogenic stage.

In southern Finland, recent research has revealed a phase of bimodal magmatism following shortly after, but clearly separate, from the dominant synorogenic magmatism in that area, including the $1865 \pm 9$ Ma Rauma diorite and the ca 1850 Ma Korpo diorite and granite (Väisänen et al. 2012a), the $1860 \pm 5$ Ma Moisio gabbro (Nevalainen et al. 2014), and ca. $1.86 \mathrm{Ga}$ post-kinematic mafic dykes (Kara et al. 2016). This magmatism is referred to as intra-orogenic by Väisänen et al. (2012a) and considered to be caused by basaltic underplating during extension of the newly formed Svecofennian crust. Similarly, the Herräng mafic dykes in east-central Sweden, although not precisely dated, are considered intraorogenic and having formed through north-south extension at some time during the 1.87-1.85 Ga period (Johansson and Karlsson 2020, and references therein). Also amphibolitic bodies within the east-west trending Avesta-Östhammar belt (Johansson and Hålenius 2013) and the basic to ultrabasic cumulate rocks in southern Roslagen (Johansson et al. 2012) may be part of the same episode of extensional magmatism, although they have not been dated. The Herräng mafic dyke swarm, the Avesta-Östhammar mafic intrusions, and the southern Roslagen cumulate rocks all occur in the same general area within the Bergslagen lithotectonic unit in eastcentral Sweden as the Hedesunda granitoid massif. Seen in that perspective, the Hedesunda I intrusion may be the most voluminous example exposed at the present surface of the 1.87-1.85 Ga bimodal intra-orogenic magmatism in eastcentral Sweden and southern Finland. It is also remarkably 


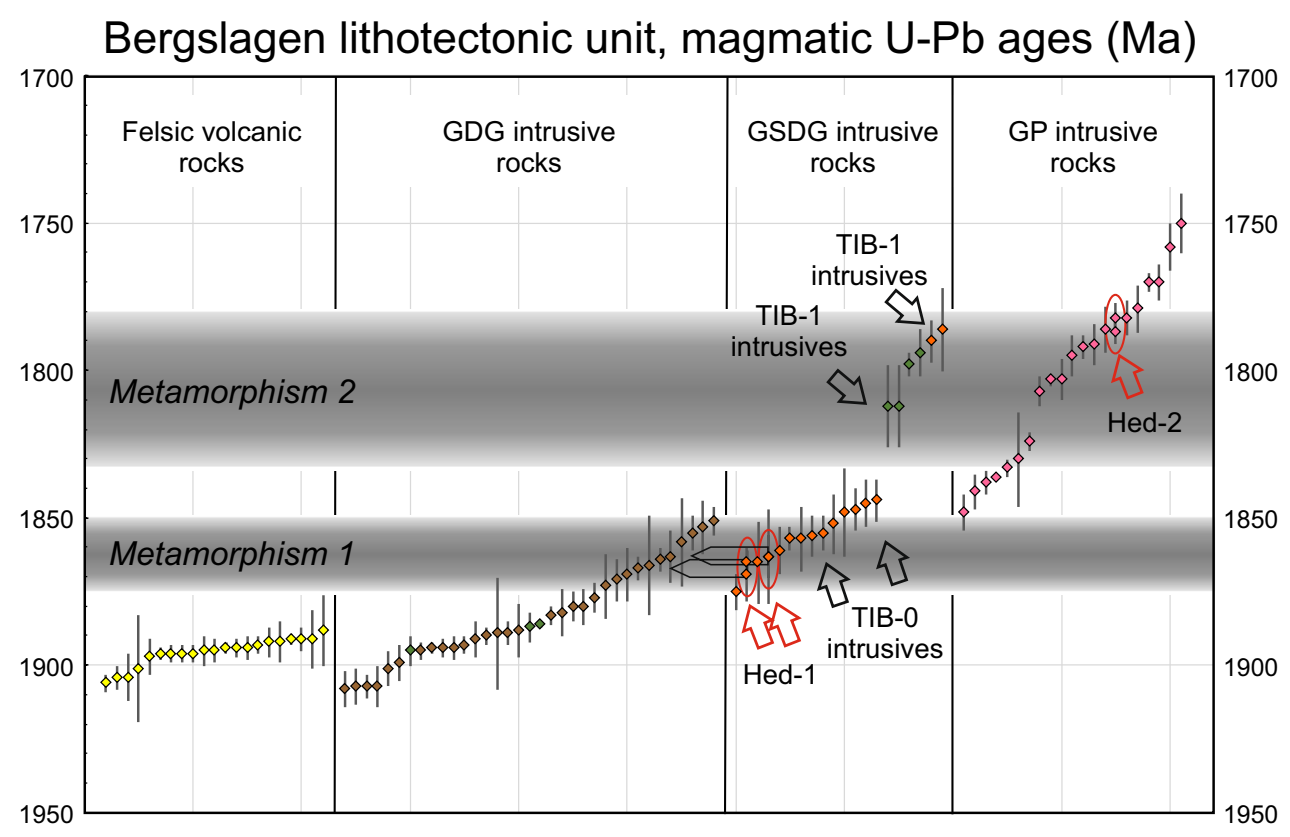

Fig. 13 Summary diagram of magmatic U-Pb ages with an uncertainty less than \pm 20 million years within the Bergslagen lithotectonic unit from the geochronological database of the Geological Survey of Sweden (SGU). Data are listed in Online Resource 4. The data points have been subdivided according to rock type, following Stephens et al. (2009): felsic volcanic rocks, granite-diorite-gabbro (GDG) suites, granite-syenite-diorite-gabbro (GSDG) suites, and granitepegmatite (GP) suites. Green symbols are gabbroic or dioritic rocks within the respective rock suite. The old (TIMS) and new (SIMS) ages from the Hedesunda I and II intrusions have been encircled and marked with red arrows. TIB-O intrusives: rock units with ages around

well preserved and little deformed, perhaps not only due to its size but also due to the fact that the Bergslagen area apparently acted as a relatively stable block during the subsequent late Svecofennian tectonism, unlike the situation in southern Finland.

As stated above, the ca 1785 Ma Hedesunda II granite, although falling within the timeframe of the late-orogenic anatectic GP rock suite within the Bergslagen lithotectonic unit, rather has A-type geochemical characteristics. Similar characteristics, however, have been found among a number of late Svecofennian granites in the Bergslagen region, such as the small Mo-W-bearing Pingstaberg, Skålhöjden, Bispbergs klack, and Högberget intrusions (Billström et al. 1988; Sundblad et al. 1993; Bergman et al. 1995; Sundblad and Bergman 1997). Also the larger 1.77-1.78 Ga Lisjö and Fellingsbro granites have similar A-type and within-plate type characteristics and are believed to have formed in an extensional environment above an east-west-trending gravity low (Öhlander and Zuber 1988; Öhlander and Romer 1996).

Through southern Finland, stretching from the Åland archipelago in the west to the lake Ladoga region in Russian
$1.85 \mathrm{Ga}$ along the southwest margin of the Bergslagen lithotectonic unit that are sometimes assigned to the TIB- 0 phase of the adjacent Transscandinavian Igneous Belt (TIB). TIB-1 intrusives: rock units with ages around $1.8 \mathrm{Ga}$ along the western margin of the Bergslagen lithotectonic unit that are similarly assigned to the TIB-1 phase of the Transscandinavian Igneous Belt. Younger TIB-2 rocks are not included in this diagram. The two shaded bands outline the ranges of metamorphic $\mathrm{U}-\mathrm{Pb}$ ages (in zircon, titanite or monazite) within the Bergslagen lithotectonic unit, as found in the SGU database and summarized by Johansson and Stephens (2017)

Karelia in the east, there is a belt of relatively small shoshonitic intrusions, referred to as post-collisional (Eklund et al. 1998; Eklund and Shebanov 2005; Andersson et al. 2006; Rutanen et al. 2011), with ages around or somewhat below $1.8 \mathrm{Ga}$ and ranging in composition from ultramafic lamprophyres to peraluminous granites. One of the most well-studied examples is the 1.79-1.76 Ga Ava ring complex in the Åland archipelago (Eklund and Shebanov 2005, and references therein), with a diameter of ca $7 \mathrm{~km}$. Other shoshonitic post-collisional intrusions in the Åland archipelago are the Seglinge, Mosshaga, and Lemland intrusions (Eklund et al. 1998; Eklund and Shebanov 2005). The central Hedesunda II intrusion is also ring-shaped with a comparable diameter $(9-11 \mathrm{~km})$ and of similar age, but is solely granitic in composition, whereas the Aland examples contain both granitic and monzonitic rocks and crosscutting lamprophyric dykes. In spite of this difference, the Hedesunda II intrusions may tentatively be considered a Swedish counterpart of this mantle-induced magmatism, although the Hedesunda II magma itself is probably dominantly of crustal origin.

It may be that the oblique Fennoscandia-Sarmatia collision (Lahtinen et al. 2005, Bogdanova et al. 2015), with 
dextral displacement of large crustal blocks, such as the Bergslagen lithotectonic unit, in a northwesterly direction (present-day coordinates) caused alternating zones of compression and extension, or transpression and transtension, giving rise to penecontemporaneous magmatism having different character. Penecontemporaneous with this oblique collision, renewed subduction-related $1.81-1.76 \mathrm{Ga}$ magmatism along the western continental margin of Fennoscandia created the TIB-I intrusions of the Transscandinavian Igneous Belt, about $120 \mathrm{~km}$ west of the Hedesunda area, attesting to the very complex tectonic situation during this time period.

\section{Summary and conclusions}

- New U-Pb SIMS zircon ages confirm earlier TIMS ages, indicating that the Hedesunda granite complex within the Bergslagen lithotectonic unit in east-central Sweden is a composite intrusion consisting of an older Hedesunda I granite at ca. $1865 \mathrm{Ma}$, and a younger Hedesunda II granite at ca. $1785 \mathrm{Ma}$, i.e. having an age difference of ca 80 million years.

- The two granitoid generations have very similar field appearances but can be separated geochemically into two groups. This separation largely confirms the geographic division between them made on recent SGU maps, based on field mapping and aeromagnetics.

- The Hedesunda I granitoids are I-type calc-alkaline intrusions ranging in composition from diorite via tonalite and granodiorite to granite (GDG trend, not GSDG as previously inferred). They are magnesian and dominantly metaluminous and formed in a continental margin setting during the 1.87-1.85-(1.83) Ga extensional, intra-orogenic phase that immediately followed the early Svecofennian synorogenic magmatism and deformation in east-central Sweden and southern Finland.

- While related mafic rocks may have formed directly from mantle-derived magma, the intermediate to felsic Hedesunda I rocks probably formed by fractional crystallization of melts generated in the juvenile Svecofennian lower crust by extension-related basaltic underplating and heating. Initial $\mathrm{Sr}, \mathrm{Nd}$, and $\mathrm{Hf}$ isotope compositions are near-chondritic to mildly depleted, compatible with formation from juvenile Svecofennian mafic lower crust.

- The Hedesunda II granitoids have a purely granitic composition. However, they are not low-temperature crustal anatectic melts, but rather high-temperature, ferroan, dominantly peraluminous, and high-K calc-alkaline to shoshonitic granites having an A-type and within-platetype character. Initial $\mathrm{Sr}$ is disturbed, but initial $\mathrm{Nd}$ and $\mathrm{Hf}$ are mildly depleted, indicating a slightly more juvenile source than for the Hedesunda I intrusion.
- The Hedesunda II granites form part of a belt of late Svecofennian post-collisional intrusions across eastcentral Sweden and southern Finland. Their magma may have formed by melting of juvenile deep crustal rocks due to renewed basaltic underplating in an extensional within-plate environment during the later stages of the Svecofennian orogeny.

Acknowledgements Open access funding provided by Swedish Museum of Natural History. The author thanks Stefan Bergman, Dick Claeson, and Fredrik Hellström at the Geological Survey of Sweden (SGU) for providing data from the geochemical and geochronological databases of the Geological Survey, and for permission to use these, and to Björn Öhlander (formerly at the Luleå University of Technology) for use of his unpublished geochemical data from the Hedesunda area contained within the SGU database. He also thanks his colleagues at the Geo department of the Swedish Museum of Natural History: Per-Olof Persson for providing the original zircon concentrates, Kerstin Lindén for turning them into polished zircon epoxy mounts, Andreas Karlsson for help with BSE imaging of zircons as well as XRD calculations of whole-rock samples, Martin Whitehouse for help with SIMS $\mathrm{U}-\mathrm{Pb}$ analyses and calculations, and Melanie Schmitt for help with LAICP-MS Lu-Hf analyses and calculations. The Nordsim-Vegacenter facility is financed by the Swedish Research Council (VR) and the Swedish Museum of Natural History with additional support from the University of Iceland. This is Nordsim contribution no. 644, and Vegacenter publication no. 027. The manuscript benefitted from comments by the journal reviewers Bernard Bonin and Patrizia Fiannacca.

Funding This article was funded by Magnus Bergvalls foundation (dnr 2017-02132).

Availability of data and material Data are available as tables or appendices (online resources) to this paper.

\section{Compliance with ethical standards}

Conflict of interest All authors declare that they have no conflict of interest.

Code availability Not applicable.

Open Access This article is licensed under a Creative Commons Attribution 4.0 International License, which permits use, sharing, adaptation, distribution and reproduction in any medium or format, as long as you give appropriate credit to the original author(s) and the source, provide a link to the Creative Commons licence, and indicate if changes were made. The images or other third party material in this article are included in the article's Creative Commons licence, unless indicated otherwise in a credit line to the material. If material is not included in the article's Creative Commons licence and your intended use is not permitted by statutory regulation or exceeds the permitted use, you will need to obtain permission directly from the copyright holder. To view a copy of this licence, visit http://creativecommons.org/licenses/by/4.0/. 


\section{References}

Andersson UB, Eklund O, Fröjdö S, Konopelko D (2006) 1.8 Ga magmatism in the Fennoscandian shield; lateral variations in subcontinental mantle enrichment. Lithos 86:110-136

Bergman S, Söderman J (2005a) Berggrundskartan 12H Söderfors NO, skala 1:50 000. Sveriges Geologiska Undersökning K 37

Bergman S, Söderman J (2005b) Berggrundskartan 13H Gävle SO, skala 1:50 000. Sveriges Geologiska Undersökning K 35

Bergman T, Schöberg H, Sundblad K (1995) Geochemistry, age and origin of the Högberget granite, western Bergslagen, Sweden. GFF 117:87-95

Bergman S, Persson P-O, Delin H, Stephens MB, Bergman T (2004) Age and significance of the Hedesunda granite and related rocks, south-central Sweden. In: Abstracts, 26th Nordic geological winter meeting, GFF, vol 126, pp 18-19

Billström K, Åberg G, Öhlander B (1988) Isotopic and geochemical data of the Pingstaberg Mo-bearing granite in Bergslagen, southcentral Sweden. Geol Mijnbouw 67:255-263

Bogdanova S, Gorbatschev R, Skridlaite G, Soesoo A, Taran L, Kurlovich D (2015) Trans-Baltic Palaeoproterozoic correlations towards the reconstruction of supercontinent Columbia/Nuna. Precambr Res 259:5-33

Bouvier A, Vervoort JD, Patchett PJ (2008) The Lu-Hf and Sm-Nd isotopic composition of CHUR: constraints from unequilibrated chondrites and implications for the bulk composition of terrestrial planets. Earth Planet Sci Lett 273:48-57

Cocherie A (1986) Systematic use of trace element distribution patterns in log-log diagrams for plutonic suites. Geochim Cosmochim Acta 50:2517-2522

Dahlin P, Johansson $\AA$, Andersson UB (2014) Source character, mixing, fractionation and alkali metasomatism in Palaeoproterozoic greenstone dykes, Dannemora area, NE Bergslagen region, Sweden. Geol Mag 151:573-590. https://doi.org/10.1017/S001675681 3000551

De Paolo DJ (1981) Neodymium isotopes in the Colorado Front Range and crust-mantle evolution in the Proterozoic. Nature 291:193-196

De Souza ZS, Martin H, Peucat J-J, Jardim de Sa EF, de Freitas Macedo MH (2007) Calc-alkaline magmatism at the Archean-Proterozoic transition: the Caico complex basement (NE Brazil). J Petrol 48:2149-2185

Debon F, Le Fort P (1983) A chemical-mineralogical classification of common plutonic rocks and associations. Trans R Soc Edinb Earth Sci 73:135-149

Defant MJ, Drummond MS (1990) Derivation of some modern arc magmas by melting of young subducted lithosphere. Nature 347:662-665

Delin H, Söderman J (2005a) Berggrundskartan 12H Söderfors NV, skala 1:50 000. Sveriges Geologiska Undersökning K 36

Delin H, Söderman J (2005b) Berggrundskartan 13H Gävle SV, skala 1:50 000. Sveriges Geologiska Undersökning K 34

Dickin AP (1995) Radiogenic isotope geology. Cambridge University Press, Cambridge

Eklund O, Shebanov A (2005) Prolonged postcollisional shoshonitic magmatism in the southern Svecofennian domain-a case study of the Ava granite-lamprophyre ring complex. Lithos 80:229-247

Eklund O, Konopelko D, Rutanen H, Fröjdö S, Shebanov AD (1998) $1.8 \mathrm{Ga}$ Svecofennian post-collisional shoshonitic magmatism in the Fennoscandian shield. Lithos 45:87-108

Frost BR, Barnes CG, Collins WJ, Arculus RJ, Ellis DJ, Frost CD (2001) A geochemical classification for granitic rocks. J Petrol 42(11):2033-2048

Griffin WL, Pearson NJ, Belousova E, Jackson SE, van Achterbergh E, O'Reilly SY, Shee SR (2000) The Hf isotope composition of cratonic mantle: LAM-MC-ICPMS analysis of zircon megacrysts in kimberlites. Geochim Cosmochim Acta 64:133-147

Harris NBW, Pearce JA, Tindle AG (1986) Geochemical characteristics of collision-zone magmatism. In: Coward MP, Reis AC (eds) Collision tectonics. Geological Society of London Special Publication 19, London, pp 67-81

Hermansson T, Stephens MB, Corfu F, Page L, Andersson J (2008) Migratory tectonic switching, western Svecofennian orogen, central Sweden: constraints from U/Pb zircon and titanite geochronology. Precambr Res 161:250-278

Högdahl K, Sjöström H, Andersson UB, Ahl M (2008) Continental margin magmatism and migmatisation in the west-central Fennoscandian Shield. Lithos 102:435-459

Högdahl K, Sjöström H, Bergman S (2009) Ductile shear zones related to crustal shortening and domain boundary evolution in the central Fennoscandian Shield. Tectonics 28(TC1003): 18. https://doi. org/10.1029/2008tc002277

Ickert RB (2013) Algorithms for estimating uncertainties in initial radiogenic isotope ratios and model ages. Chem Geol 340:131-138

Irvine TN, Baragar WRA (1971) A guide to the chemical classification of the common volcanic rocks. Can J Earth Sci 8:523-548

Jacobsen SB, Wasserburg GJ (1984) Sm-Nd isotopic evolution of chondrites and achondrites. II. Earth Planet Sci Lett 67:137-150

Jeon H, Whitehouse MJ (2015) A critical evaluation of U-Pb calibration schemes used in SIMS zircon geochronology. Geostand Geoanal Res 39:443-452

Johansson Å, Hålenius U (2013) Palaeoproterozoic mafic intrusions along the Avesta-Östhammar belt, east-central Sweden: mineralogy, geochemistry and magmatic evolution. Int Geol Rev 55:131157. https://doi.org/10.1080/00206814.2012.684455

Johansson A, Karlsson A (2020) The 'intraorogenic' Svecofennian Herräng mafic dyke swarm in east-central Sweden: age, geochemistry and tectonic significance. GFF 142:1-22. https://doi. org/10.1080/11035897.2019.1708450

Johansson $\AA$, Stephens MB (2017) Timing of magmatism and migmatization in the $2.0-1.8 \mathrm{Ga}$ accretionary Svecokarelian orogen, south-central Sweden. Int J Earth Sci 106:783-810. https://doi. org/10.1007/s00531-016-1359-3

Johansson Å, Andersson UB, Hålenius U (2012) Petrogenesis and geotectonic setting of early Svecofennian arc cumulates in the Roslagen area, east-central Sweden. Geol J 47:557-593. https:// doi.org/10.1002/gj.2416

Kara J, Väisänen M, Lahaye Y, O’Brien H (2016) Post-kinematic mafic dykes in southern part of Central Svecofennia, Finland. Extended abstract, Lithosphere 2016 symposium, Nov. 9-11, 2016, Espoo, Finland, $\mathrm{p} 47-50$

Lahtinen R, Korja A, Nironen M (2005) Paleoproterozoic tectonic evolution. In: Lehtinen M, Nurmi P, Rämö OT (eds) Precambrian geology of Finland: key to the evolution of the Fennoscandian shield. Elsevier B.V., Amsterdam, pp 481-532

Ludwig KR (2003) A Geochronological Toolkit for Microsoft Excel. Berkeley Geochronological Center, Special Publication No. 4

Maniar PD, Piccoli PM (1989) Tectonic discrimination of granitoids. Geol Soc Am Bull 101:635-643

McCulloch MT, Chappell BW (1982) Nd isotopic characteristics of S- and I-type granites. Earth Planet Sci Lett 58:51-64

Middlemost EAK (1994) Naming materials in the magma/igneous rock system. Earth Sci Rev 37:215-224

Nevalainen J, Väisänen M, Lahaye Y, Heilimo E, Fröjdö S (2014) Svecofennian intra-orogenic gabbroic magmatism: a case study from Turku, southwestern Finland. Bull Geol Surv Finl 86:93-112

Öhlander B, Romer RL (1996) Zircon ages of granites occurring along the central Swedish gravity low. GFF 118:217-225 
Öhlander B, Zuber J (1988) Genesis of the Fellingsbro-type granites: evidence from gravity measurements and geochemistry. GFF 110:39-54

Pearce JA (1996) Sources and settings of granitic rocks. Episodes 19:120-125

Pearce JA, Harris NBW, Tindle AG (1984) Trace element discrimination diagrams for the tectonic interpretation of granitic rocks. J Petrol 25:956-983

Peccerillo A, Taylor SR (1976) Geochemistry of Eocene calc-alkaline volcanic rocks from the Kastamonu Area, Northern Turkey. Contrib Miner Petrol 58:63-81

Persson L, Persson P-O (1997) U-Pb datings of the Hedesunda and Åkersberga granites of south-central Sweden. GFF 119:91-95

Pin C, Zalduegui JFS (1997) Sequential separation of light rare-earth elements, thorium and uranium by miniaturized extraction chromatography: application to isotopic analyses of silicate rocks. Anal Chim Acta 339:79-89

Robinson FA, Pease V, Whitehouse MJ, Kooijman E (2018) Preliminary detrital zircon signatures from the southern Asir terrane, Saudi Arabia: a link to Yemen or the Nubian Shield? Precambr Res 311:247-261

Rutanen H, Andersson UB (2009) Mafic plutonic rocks in a continental-arc setting: geochemistry of 1.87-1.78 Ga rocks from southcentral Sweden and models of their palaeotectonic setting. Geol J 44:241-279

Rutanen H, Andersson UB, Väisänen M, Johansson Å, Fröjdö S, Lahaye Y, Eklund O (2011) 1.8 Ga magmatism in southern Finland: strongly enriched mantle and juvenile crustal sources in a post-collisional setting. Int Geol Rev 53:1622-1683. https://doi. org/10.1080/00206814.2010.496241

Sandegren R, Asklund B (1948) Beskrivning till kartbladet Söderfors. Sveriges Geologiska Undersökning Aa 190

Sandegren R, Lundegårdh PH (1949) Beskrivning till kartbladet Untra. Sveriges Geologiska Undersökning Aa 191

Shand SJ (1943) Eruptive rocks. Their genesis, composition, classification, and their relation to ore-deposits with a chapter on meteorite. Wiley: New York

Spencer CJ, Kirkland CL, Roberts NMW, Evans NJ, Liebmann J (2020) Strategies towards robust interpretations of in situ zircon $\mathrm{Lu}-\mathrm{Hf}$ isotope analyses. Geosci Front 11:843-853

Stacey JS, Kramers JD (1975) Approximation of terrestrial lead isotope evolution by a two-stage model. Earth Planet Sci Lett 26:207-221

Stephens MB, Andersson J (2015) Migmatization related to mafic underplating and intra- or back-arc spreading above a subduction boundary in a 2.0-1.8 Ga accretionary orogen, Sweden. Precambr Res 264:235-257

Stephens MB, Jansson NF (2020): Paleoproterozoic (1.9-1.8 Ga) synorogenic magmatism, sedimentation and mineralization in the Bergslagen lithotectonic unit, Svecokarelian orogen. In Stephens MB, Bergman Weihed J (eds) Sweden: lithotectonic framework, tectonic evolution and mineral resources. Geological Society Memoir, vol 50, pp 155-206

Stephens MB, Ahl M, Bergman T, Lundström I, Persson L, Ripa M, Wahlgren C-H (2007) Regionala geologiska och geofysiska kartor över Bergslagen med omgivning. Berggrundskarta, skala 1:400 000. Sveriges Geologiska Undersökning, vol Ba 58, part 1

Stephens MB, Ripa M, Lundström I, Persson L, Bergman T, Ahl M, Wahlgren C-H, Persson P-O, Wickström L (2009) Synthesis of bedrock geology in the Bergslagen region, Fennoscandian Shield, south-central Sweden. Sveriges Geologiska Undersökning, vol Ba 58 , pp 259

Streckeisen A (1976) To each plutonic rock its proper name. Earth Sci Rev 12:1-33

Sun SS, McDonough WF (1989) Chemical and isotopic systematics of ocean basalts: implications for mantle composition and processes. In AD Saunders and MJ Norry (eds.): Magmatism in Ocean Basins. Geological Society of London Special Publications 42, pp 313-345

Sundblad K, Bergman T (1997) "Late Svecofennian" granitoids. In: Ahl M, Andersson UB, Lundqvist T, Sundblad K (eds) Rapakivi granites and related rocks in central Sweden, $\mathrm{p} 7-15$. Sveriges Geologiska Undersökning Ca 87, p 99

Sundblad K, Ahl M, Schöberg H (1993) Age and geochemistry of granites associated with Mo-mineralization in western Bergslagen, Sweden. Precambr Res 64:319-335

Väisänen M, Eklund O, Lahaye Y, O'Brien H, Fröjdö S, Högdahl K, Lammi M (2012a) Intra-orogenic Svecofennian magmatism in SW Finland constrained by LA-MC-ICP-MS zircon dating and geochemistry. GFF 134:99-114

Väisänen M, Johansson Å, Andersson UB, Eklund O, Hölttä P (2012b) Palaeoproterozoic adakite- and TTG-like magmatism in the Svecofennian orogen, SW Finland. Geol Acta 10:351-371. https ://doi.org/10.1344/105.00000176

Villa IM, De Bièvre P, Holden NE, Renne PR (2015) IUPAC-IUGS recommendation on the half life of ${ }^{87} \mathrm{Rb}$. Geochim Cosmochim Acta 164:382-385

Whalen JB, Currie KL, Chappel BW (1987) A-type granites: chemical characteristics, discrimination and petrogenesis. Contrib Miner Petrol 95:407-419

Whitehouse MJ, Kamber BS (2005) Assigning dates to thin gneissic veins in high-grade metamorphic terranes: a cautionary tale from Akilia, southwest Greenland. J Petrol 46:291-318

Whitehouse MJ, Kamber BS, Moorbath S (1999) Age significance of $\mathrm{U}-\mathrm{Th}-\mathrm{Pb}$ zircon data from early Archaean rocks of west Greenland - a reassessment based on combined ion microprobe and imaging studies. Chem Geol 160:201-224

Wiedenbeck M, Allé P, Corfu F, Griffin WL, Meier M, Oberli F, von Quadt A, Roddick JC, Spiegel W (1995) Three natural zircon standards for $\mathrm{U}-\mathrm{Th}-\mathrm{Pb}, \mathrm{Lu}-\mathrm{Hf}$, trace element and REE analyses. Geostand Newsl 19:1-23

Winchester JA, Floyd PA (1977) Geochemical discrimination of different magma series and their different products using immobile element. Chem Geol 20:325-343

Woodhead JD, Hergt JM (2005) A preliminary appraisal of seven natural zircon reference materials for in situ $\mathrm{Hf}$ isotope determination. Geostand Geoanal Res 29:183-195 